\title{
Transport Accessibility and Tourism Development Prospects of Indigenous Communities of Siberia
}

\author{
Maria Kuklina ${ }^{1, *(1)}$, Denis Dirin ${ }^{2}$, Viktoriya Filippova ${ }^{3}$, Antonina Savvinova ${ }^{4}$, Andrey Trufanov ${ }^{5}(\mathbb{0}$, \\ Natalia Krasnoshtanova ${ }^{6}$, Viktor Bogdanov ${ }^{6}$, Dmitrii Kobylkin ${ }^{6}$, Alla Fedorova ${ }^{4} \mathbb{D}$, Anna Itegelova ${ }^{4} \mathbb{C}$ \\ and Eduard Batotsyrenov ${ }^{7}$
}

check for updates

Citation: Kuklina, M.; Dirin, D.; Filippova, V.; Savvinova, A.; Trufanov, A.; Krasnoshtanova, N.; Bogdanov, V.; Kobylkin, D.; Fedorova, A.; Itegelova, A.; et al. Transport Accessibility and Tourism Development Prospects of Indigenous Communities of Siberia. Sustainability 2022, 14, 1750. https:/ / doi.org/10.3390/su14031750

Academic Editors: Lóránt Dénes Dávid, Laszlo Vasa, Setiawan Priatmoko and Yoonjae Nam

Received: 19 December 2021

Accepted: 31 January 2022

Published: 3 February 2022

Publisher's Note: MDPI stays neutral with regard to jurisdictional claims in published maps and institutional affiliations.

Copyright: (c) 2022 by the authors. Licensee MDPI, Basel, Switzerland. This article is an open access article distributed under the terms and conditions of the Creative Commons Attribution (CC BY) license (https:// creativecommons.org/licenses/by/ $4.0 /)$.
1 Institute of High Technology, Irkutsk National Research Technical University, 664074 Irkutsk, Russia

2 Institute of Earth Sciences, University of Tyumen,625002 Tyumen, Russia; d.a.dirin@utmn.ru

3 The Institute for Humanities Research and Indigenous Studies of the North, SB RAS, 677027 Yakutsk, Russia; filippovav@mail.ru

4 Institute of Natural Sciences, M.K. Ammosov North-Eastern Federal University, 677000 Yakutsk, Russia; sava_73@mail.ru (A.S.); fedas78@mail.ru (A.F.); itegelova@mail.ru (A.I.)

5 Institute of Information Technology and Data Science, Irkutsk National Research Technical University, 664074 Irkutsk, Russia; troufan@gmail.com

6 V B Sochava Institute of Geography, SB RAS, 664033 Irkutsk, Russia; knesun@mail.ru (N.K.); victvss@gmail.com (V.B.); agrembrandt@inbox.ru (D.K.)

7 Baikal Institute of Nature Management, SB RAS, 670047 Ulan-Ude, Russia; edikbat@gmail.com

* Correspondence: kuklina-kmv@yandex.ru; Tel.:+ 7-9246246249

\begin{abstract}
This paper aims to identify details of interaction and mutual influence of tourism and transport infrastructure development using a combination of sociological and statistical methods. For the analysis, five key sites were selected in several parts of Siberia, differing in natural, socioeconomic, and ethnocultural quality, but possessing the presence of compact indigenous communities that reproduce traditional forms of both cultural life and economic activity. While each community has its own unique culture and resources for development, several similar characteristics were revealed. It has been revealed that tourists themselves and workers of the tourism sector, including local residents, are unequivocal supporters of transportation system development. A significant part of the population, recognizing the need and advantages of having a well-functioning transport infrastructure, expresses a negative attitude towards easy accessibility of the territory for outsiders who violate the rules and regime for usage of natural resources and augment economic and cultural competition for the local population. Understanding key processes of interrelations, both explicit and hidden, concomitant to socioeconomic development of remote indigenous communities, with the simultaneous development of tourism and transport, allows the authors to propose a model outline of attitudes of local communities towards tourist and transport perspectives in the territory of their residence.
\end{abstract}

Keywords: transport; Todzhinsky kozhuun; Okinsky district; Tyndinsky district; Neryungrinsky district; transport infrastructure; mining industry; Indigenous communities of the North and Siberia; remote territories; accessibility; tourism

\section{Introduction}

The Sustainable Development Goals (SDGs) for the period up to 2030 were announced in September 2015 at the historic UN summit [1]. According to Brundtland Commission Report, sustainable development is interpreted as: "development that meets the needs of the present without compromising the ability of future generations to meet their own needs" [2]. To achieve sustainable development it is crucial to balance three of its principal dimensions: economic growth, social inclusion, and environmental protection. However, with specific steps aimed at implementation of territorial or sectoral components in sustainable 
development, contradictions often arise due to diverse interests of participants in the processes. These contradictions can be most clearly observed in tourism development of remote areas with a compact residence of indigenous communities, abiding, by the most part, to their traditional way of life.

Often, these territories, possessing high tourist and recreational potential, are characterized by both an underdeveloped transport infrastructure and a low level of socioeconomic development in general. From the standpoint of the market-consumer paradigm of modern society, such districts being far from the main centers of concentrated population and economy are depressed and uncompetitive. Tourism development for such territories is more often perceived by decision makers (representatives of regional and federal authorities) as an undoubted benefit and a good chance to stimulate the socioeconomic development of the region and improve the quality of life of the local population.

However, the spontaneous tourism development, as well as transport development of the territory without considering the opinion of the local population, can lead to serious contradictions and conflicts and contribute to the degradation and destruction of traditional cultural landscapes. Thus, there are complex multidimensional and multi-vector relationships and mutual influences in the system "local population-transport-tourism". These connections have both common fundamental laws and their own regional and local features.

All of them must be understood and considered when planning sustainable development of the territory.

The aim of the study is to identify general patterns and particular regional features of the co-development of tourism, transport, and local communities in underdeveloped territories of compact residence of indigenous peoples abiding to a traditional way of life.

The objectives of the study were:

1. identification of regional contexts in interrelations for development of transport systems and tourism in the studied territories (natural, socioeconomic, ethnocultural, institutional factors);

2. analysis of impact of the development of transport networks and the tourism industry on local communities;

3. model characteristics of indigenous communities' attitude to tourism and transport development in the territories of their residence.

The model territory of the study is the underdeveloped regions of Siberia with areas of compact residence of the indigenous population leading a traditional way of life. Okinsky district of the Buryatia Republic, Todzhinsky kozhuun (district) of the Tyva Republic, Neryungrinsky district of the Sakha Republic (Yakutia), Tyndinsky district of the Amur Region, and the Altai Republic are such research sites. They differ from each other in area, natural conditions, available tourist and recreational potential, and the level of tourism development. However, each of them can be considered peripheral with respect to the centers of settlement and economic activity, and also in each of them there are compact groups of the indigenous population leading a traditional way of life. In these territories, during several field seasons, expeditionary work was carried out, during which nonincluded observation, questioning, and interviewing of the population were performed.

\section{Related Works}

As the paper [3] emphasizes, one of the main factors hindering tourism development is limited transport accessibility, seasonality, lack of qualified personnel, and an insufficient quantity of hotels. Contrarily, in other countries located in similar geographic areas, there is an increase in tourism (for example, northern Finland, the Yukon province in Canada, Alaska in the United States). In such regions, infrastructure provision comes to the forefront [4]. Thus, it is of value to define the institutional and sociocultural characteristics of tourism development and its dependence on transport accessibility of the territory.

Exploration into impact of transport infrastructure on regional and global development continues to attract particular interest in the international scientific community. On the 
one hand, researchers are interested in economic aspects and the effects of the influence of transport routes on the level of economic development of regions of different geographical locations [5-9]. On the other hand, they draw attention to social issues, such as population mobility and aspects related to quality of life [10,11].

Pertinent strengthening of the role of transport infrastructure in territorial development is also noted in the Transport Strategy of the Russian Federation until 2030 [12]. Anthropological approaches in studying mobility are represented by road anthropology $[10,13,14]$. Experts noted relationships between physical distances and transport accessibility, but mobility processes of local communities still remain poorly understood, especially in remote areas [15].

The topic of studying influences of various transport systems on local community for remote areas of the North is especially important [16-18]. In this regard, transport accessibility is one of the most important factors regulating the level of socioeconomic development of a particular territory [5,19], and especially for the Siberian and Far Eastern regions of Russia [18].

Limitations of transport accessibility and the definition of transport remoteness are primarily associated with physical distances and development of transport infrastructure, while experience and practices of mobility of local residents are often out of focus. However, at the same time, fencing from the outside world in the form of abandoning highways may be a local population's own choice [20]. Spatial isolation has its own priorities. So, local communities, for the most part, consider isolation and absence of roads as a blessing that provides them with a feeling of almost complete freedom and opportunity to abide by a lifestyle they prefer in a calm, understandable, world of their own [21].

It should be noted that transport accessibility is interpreted in a different way in nomadic cultures than in those of sedentary [22]. Moreover, accessibility for the latter group is not considered as some kind of problem, differing only in speed of human, material, and information flows, where the issues of the existing trajectories of people, cargo, information, etc., between a certain locality and the outside world, as well as obstacles, hindrances, and restrictions in their movement, come to the focus.

Currently, many indigenous peoples live on the territory of Siberia, whose way of life might be generally described as traditional. This, in particular, implies the reproduction of extensive nature-adaptive forms of economic activity (nomadic or semi-nomadic animal husbandry, forestry, etc.), and special forms of interaction with the environment. As a result of centuries-old adaptation to the conditions of the local environment, indigenous communities have created unique cultural landscapes in which the material and spiritual elements of culture and the natural features of the territory harmoniously penetrate each other [23]. However, the Soviet and post-Soviet period of industrialization of Siberia and the interaction of small indigenous communities with a mass culture of an innovative type showed their extremely weak resistance to the processes of cultivation and assimilation. Destruction of traditional cultural landscapes, cultural unification, rejection of traditions not only reduces cultural diversity and deprives humanity of a significant part of the unique cultural heritage, but also leads to social degradation of the communities of the indigenous population [24].

At the same time, the underdeveloped territories of Siberia, where indigenous peoples live, are the most depressed regions of Russia, in socioeconomic terms [25]. Such conditions affect the quality of life of the population [26] and requires regional and federal governments to take measures to improve the socioeconomic situation in these regions. Very often, for such underdeveloped territories, interested in natural and ethnocultural respects, development of tourism is proposed as a panacea for solving socioeconomic problems [27]. To stimulate tourism, first of all, they strive to ensure the transport accessibility of the territory.

To date, the small indigenous peoples of Siberia have formed special local ethnic groups with their own cultural characteristics and economic activities in the places of settlement. Administrative-territorial division, as well as industrial and transport development in the twentieth century, had a great influence on their locating. 
A historical retrospective of the development of interregional and intraregional communications in the places of residence of indigenous peoples shows that from time immemorial, they communicated with each other despite remoteness and absence of official roads. Here, the role of unofficial routes in such a kind of communication comes to the forefront. In areas where the mining industry is developing, such informal roads are also represented by networks of various technological ones, which can be either active or already abandoned [28]. These roads are often used, to some extent, informally by the local population, both for travel on their lands of traditional natural use and for communication with other settlements.

Currently, the role of informal roads is not well understood, despite its important component in the life of indigenous peoples. Until now, indigenous peoples use the old trails to travel to their own and neighboring lands. Often, people on informal roads visit their relatives from other constituent entities of Russia and go on holidays, where there is an opportunity to communicate in their native language and show their culture. In hard-to-reach areas, tourists are also transported along old roads, which causes an ambiguous assessment from the local population. The development of tourism in places where indigenous peoples live is seen as one of the paths to sustainable development. This article examines the positive and negative aspects of tourism development in the regions where the indigenous peoples of Siberia live.

The scientific community is searching for a place and role of tourism in achieving sustainable development goals (SDGs), from understanding the very nature of the phenomenon [29] to analyzing indicators of sustainable tourism in relation to SDGs [30], not forgetting restrictions associated with environmental protection.

Sustainable tourism, according to the definition of the World Tourism Organization (WTO), is understood as "tourism that takes full responsibility for the current and future economic, social and environmental development, taking into account the interests of tourists, entrepreneurship, local communities and environmental protection" [31]. In the study [32], the author considered sustainable tourism as an alternative to mass tourism, which implies a significant recreational load. Mass tourism is dangerous because its uncontrolled growth leads to environmental problems, destruction of unique natural sites, degradation of cultural landscapes, and, as result, decreases attractiveness of the destination, etc. Sustainable tourism meets both the needs of tourists and considers the needs of the local population while maintaining and increasing opportunities for the future.

According to [33], effectiveness of sustainable tourism development is ensured by involving local communities to improve their economic wellbeing and quality of life, while minimizing negative impacts on ecological and sociocultural nature. The author also noted that more and more tourists are losing interest in today's dominant mass, or so-called "beach" types of recreation and are ready to incur significant costs to visit cultural and historical sites, parks, natural zones, and especially protected areas of wildlife, including in cultivated (most often rural) landscapes, acquaintance with cultures and customs of local populations, turning more personalized ecological tourism and its modifications (green, rural, agritourism, recreational, gastronomic tourism, bio-tourism, etc.) into the most demanded and dynamic type of tourist activity.

It should be remembered that the development of tourism is aimed at fulfilling important social functions: creating jobs for such categories of population as youth, women, rural residents (especially in terms of development of rural, ecological, and ethnic tourism). This area does not require either high qualifications of employees or concentration of scientific and technical potential: this is extremely important for development of depressed regions. Sustainable tourism is capable of influencing by its development such key sectors of economy as transport, communications, construction, agriculture, and thus tourism can be considered as a certain trigger of the socioeconomic development of the region. 


\section{Methods}

The research methods we used include in-depth and group interviews with local residents, non-included observations, expert interviews, analysis of statistical data, municipal reports and archival materials, and surveys. The theoretical and methodological platform is based on the scientific works of domestic and foreign authors on topics and territories under study.

If compared with other research techniques, such as statistical analysis, questionnaires, correlation analysis, expert and other methods of interviewing, interviewing has a number of undoubted advantages. In particular, statistics provide indirect data on the mutual influence of the development of transport infrastructure and tourism, as well as changes in lives of local communities. At the same time, the correlation between improving the transport infrastructure in a territory, i.e., with an increase in tourist traffic, is unprovable without additional research, since many other factors can have an impact (advertising, government programs to support local communities, etc.). In addition, statistical analysis does not allow a researcher to understand types of relationships and causes of processes that occur. Principal disadvantage of questionnaire research is that formulation of questions predetermines, to a large extent, the results of the questionnaire. That is, subjective opinions and personal experiences of scientists will certainly influence the research results. In contrast, interviewing allows explorers to obtain conditionally "pure" knowledge directly from representatives of the studied local communities, and then only generalize and interpret their statements, preserving from imbedding into their own hypotheses

The administrative regions of our research are territories of five constituent entities of the Russian Federation: Todzhinsky kozhuun, Tyva Republic, Okinsky district, Republic of Buryatia, and Tyndinsky district, Amur region, Neryungri district, Sakha Republic (Yakutia), as well as the Altai Republic (Table 1). Allocation of municipal districts as equivalent cases, on the one hand, and the subject of the Russian Federation (the Altai Republic) is due to comparability of the areas of all the territories.

Table 1. Field Study Sites and Interviewees.

\begin{tabular}{cccc}
\hline Community & $\begin{array}{c}\text { Number of } \\
\text { Interviewees }\end{array}$ & $\begin{array}{c}\text { Local/Indigenous } \\
\text { Residents (LR) }\end{array}$ & $\begin{array}{c}\text { Government } \\
\text { Officials (GO) }\end{array}$ \\
\hline Toora-Khem & 15 & 12 & 3 \\
\hline Orlik & 15 & 13 & 2 \\
\hline Pervomaisky & 10 & 7 & 3 \\
\hline Iengra & 12 & 9 & 2 \\
\hline Ust-Urkima & 10 & 8 & 2 \\
\hline Elekmonar & 6 & 4 & 2 \\
\hline Edigan & 5 & 3 & 2 \\
\hline Kurai & 6 & 4 & 2 \\
\hline Beltir & 4 & 4 & 1 \\
\hline Balyktuul & 6 & 4 & \\
\hline Multa & 6 & 4 & 2 \\
\hline Karagay & 5 & 4 & 2 \\
\hline
\end{tabular}

Due to more intensive tourism development in the Altai Republic and the multiplicity of manifestations in interaction of transport, tourism, and local population, the territory was studied in more detail with the use of a larger number of control points (seven villages in four administrative districts, namely Chemalsky, Ust-Koksinsky, Ulagansky, and Kosh-Agachsky). 
Field studies were carried out in August 2020 and October 2021 in Okinsky district, in August 2021 in Todzhinsky kozhun, and in September 2021 in Tyndinsky and Neryungri districts. The interviewees were found using the snowball method and social networks.

As for the "snowball" sampling method, this is a special case of a non-probabilistic sampling using a small pool of original informants [34]. Each interviewee of a starting group provides the explorer with the names of further interviewees. The latter, in turn, give the names of the next interviewees, and so on.

It is applied to relatively small general populations, the specificity of which is that, firstly, the interviewees know each other and, secondly, it is difficult for them to obtain a representative sample. The procedure ends when new names stop appearing. The resulting sample is representative in the sense that it includes the most famous representatives of the general population.

In our study, the number of respondents depended on the number of days researchers spent in the site. The content of the survey was explained to the respondents, and their names were coded. All the interviews were conducted individually.

During the interview, special attention was paid to free expression of opinion by respondents while guaranteeing concomitant confidentiality. Often, the respondents did not limit themselves to short answers to the questions, but gave detailed answers with examples, personal plans, and thoughts on ways to improve local life in line with development of transport links and tourism. Such opinions contribute to a deeper understanding of the problem of development of transport and communications, and other socioeconomic, technological, and environmental processes.

Duration of the interviews ranged from 25 to $90 \mathrm{~min}$ and averaged 50 to $60 \mathrm{~min}$.

While processing interviews, we grouped respondents by gender, age, nationality, and other characteristics, which leveled personal nature of the interviewees and made it possible to identify a general trend in opinions of the population. Interviews were conducted with representatives of various spheres of activity: heads of administrations, representatives of communities, directors of enterprises, employees of public spheres, agriculture, industrial companies, and other people who wished to be interviewed.

For people with different powers of authority, there was a set of scheduled questions. However, in ordinary interviews, we asked questions which arose spontaneously during the conversation, due to the content of the conversation. In a number of cases, special interest was taken in events of the past in order to better understand dynamics of public consciousness on various topical issues. This promotes researchers to clarify contemporary processes of democratization as well.

Duration of the interviews ranged from 25 to $90 \mathrm{~min}$ and averaged 50 to $60 \mathrm{~min}$.

Fifteen interviews were conducted in the Okinsky district (Orlik Village), 15 interviews in Todzhinsky district (Toora-Khem village), 12 interviews in Neryungri district (Iengra Village), in Tyndinsky district (Pervomaisky village; 10 interviews), the Ust-Urkima village (10 interviews), and in 7 villages of the Altai Republic (38 interviews). The respondents were representatives of local communities who were from 18 to 58 years old, males and females, both included in the tourism industry and not related to tourism.

\section{Study Area}

In our research, we focused on the areas where indigenous peoples live. The characteristics of the study areas are presented in Tables 2 and 3. The map of the study areas is presented in the Figure 1.

\subsection{Case 1. Todzhinsky Kozhuun, Republic of Tyva}

Todzhinsky kozhuun occupies the entire northeastern part of the Republic of Tyva and borders on Kaa-Khemsky, Kyzyl, Piy-Khem regions of Tyva, the Republic of Buryatia, the Irkutsk region, and Krasnoyarsk Territory (Figure 2). The boundaries run mainly along the watersheds of mountain ranges and uplands. 


\section{Legeng}

Study area

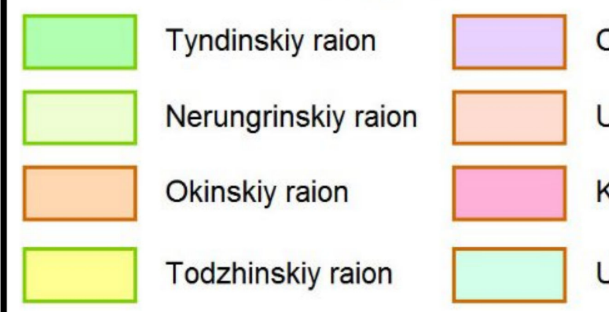

Chemalsky rayon

Ulagansky rayon

Kosh-Agachsky rayon

Ust-Koksinsky rayon

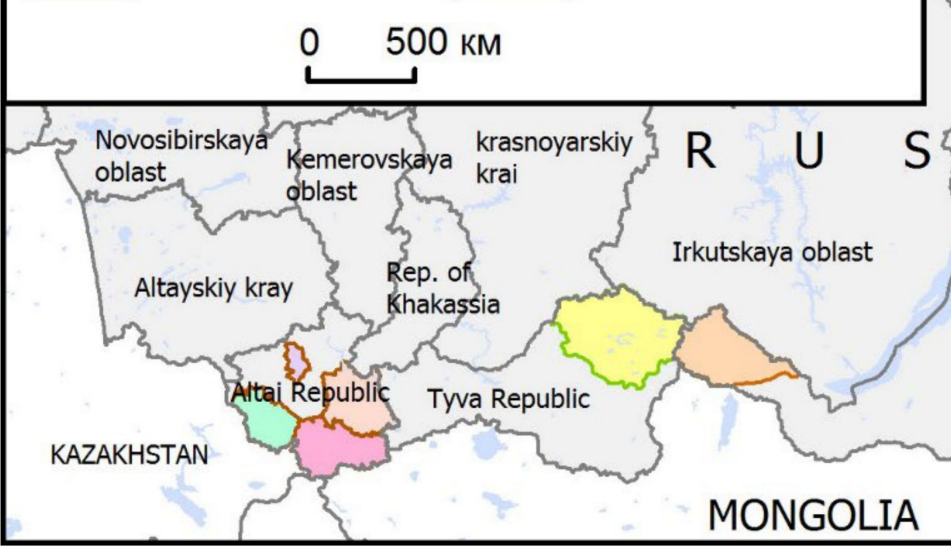

Figure 1. Map of study areas.

Table 2. Characteristics of the study areas.

\begin{tabular}{|c|c|c|c|c|c|}
\hline Study Areas & $\begin{array}{c}\text { The Area of } \\
\text { the Land }\end{array}$ & District Center & $\begin{array}{l}\text { Distance from the District } \\
\text { Center to the } \\
\text { Administrative Center of } \\
\text { the Region, Republic }\end{array}$ & $\begin{array}{c}\text { Population of } \\
\text { the District }\end{array}$ & $\begin{array}{c}\text { Ethnic } \\
\text { Composition } \\
\text { of Districts }\end{array}$ \\
\hline $\begin{array}{c}\text { Todzhinsky } \\
\text { kozhuun }\end{array}$ & 44.8 thousand $\mathrm{km}^{2}$ & $\begin{array}{c}\text { Toora-Khem } \\
\text { village }\end{array}$ & $230 \mathrm{~km}$ to Kyzyl & 6649 & $\begin{array}{c}\text { Tojins: } 44.7 \% \\
\text { Tuvans: } 33.6 \% \\
\text { Russians: } 19.8 \%\end{array}$ \\
\hline $\begin{array}{l}\text { Okinsky } \\
\text { district }\end{array}$ & 26.6 thousand $\mathrm{km}^{2}$ & Orlik village & $700 \mathrm{~km}$ to Ulan-Ude & 5452 & $\begin{array}{c}\text { Soyoty: } 59.9 \% \\
\text { Buryats: } 33.3 \% \\
\text { Others: } 6.8 \%\end{array}$ \\
\hline $\begin{array}{l}\text { Tyndinsky } \\
\text { district }\end{array}$ & 83.3 thousand $\mathrm{km}^{2}$ & Tynda town & $824 \mathrm{~km}$ to Blagoveshchensk & 13,013 & $\begin{array}{c}\text { Russians: } 81.2 \% \\
\text { Koreans: } 2.7 \% \\
\text { Tatars: } 1.1 \% \\
\text { Ukrainians: } 0.4 \% \\
\text { Evenki: } 0.4 \% .\end{array}$ \\
\hline $\begin{array}{l}\text { Neryungri } \\
\text { district }\end{array}$ & 98.8 thousand $\mathrm{km}^{2}$ & Neryungri town & $808 \mathrm{~km}$ to Yakutsk & 74,900 & $\begin{array}{c}\text { Russians: } 78 \% \\
\text { Ukrainians: } 6.2 \% \\
\text { Evenki: } 1.4 \% \\
\text { Others: } 14.4 \%\end{array}$ \\
\hline $\begin{array}{c}\text { Altai } \\
\text { Republic }\end{array}$ & 92,6 thousand $\mathrm{km}^{2}$ & $\begin{array}{l}\text { Gorno-Altaysk } \\
\text { town }\end{array}$ & $\begin{array}{c}\text { Distance from } \\
\text { Gorno-Altaysk to regional } \\
\text { centers from } 10 \mathrm{~km} \text { (Maima) } \\
\text { to } 460 \mathrm{~km} \text { (Kosh-Agach) }\end{array}$ & 220,954 & $\begin{array}{c}\text { Russians: } 56.6 \% \\
\text { Altaians: } 33.9 \% \\
\text { Kazakhs: } 6.2 \% \\
\text { Others: } 3.3 \%\end{array}$ \\
\hline
\end{tabular}


Table 3. Characteristics of study settlements.

\begin{tabular}{|c|c|c|c|c|}
\hline $\begin{array}{l}\text { Key } \\
\text { Settlements }\end{array}$ & Population & $\begin{array}{l}\text { Representatives of } \\
\text { Indigenous } \\
\text { Minorities }\end{array}$ & Traditional Branches of the Economy & Transport Links \\
\hline $\begin{array}{l}\text { Toora-Hem } \\
\text { village }\end{array}$ & 2387 & Tuvan-Tojin & Reindeer husbandry & $\begin{array}{l}\text { Automobile dirt road } \\
\text { through the ferry, a } \\
\text { bridge is being built }\end{array}$ \\
\hline Orlik village & 2555 & Soyots & Reindeer breeding and yak breeding & Automobile dirt road \\
\hline $\begin{array}{l}\text { Ust-Urkima } \\
\text { village }\end{array}$ & 260 & Evenki & $\begin{array}{l}\text { Hunting and fishing, } \\
\text { reindeer husbandry }\end{array}$ & $\begin{array}{l}\text { Highway, } 28 \mathrm{~km} \text { to the } \\
\text { south, Larba station on } \\
\text { the BAM. }\end{array}$ \\
\hline $\begin{array}{l}\text { Iyengra } \\
\text { village }\end{array}$ & 917 & Evenki & $\begin{array}{l}\text { Hunting and fishing, reindeer } \\
\text { husbandry }\end{array}$ & $\begin{array}{l}\text { Federal highway A360 } \\
\text { (formerly M56) "Lena" }\end{array}$ \\
\hline $\begin{array}{l}\text { Elekmonar } \\
\text { village }\end{array}$ & 1895 & Altai-kizhi & $\begin{array}{l}\text { Driving cattle breeding (sheep } \\
\text { breeding, horse breeding, cattle } \\
\text { breeding), hunting }\end{array}$ & $\begin{array}{l}\text { The road with a solid } \\
\text { Automobile cover } \\
\text { "Chemalsky tract" }\end{array}$ \\
\hline $\begin{array}{l}\text { Edigan } \\
\text { village }\end{array}$ & 246 & Altai-kizhi & $\begin{array}{l}\text { Driving cattle breeding (sheep } \\
\text { breeding, horse breeding, cattle } \\
\text { breeding), hunting }\end{array}$ & Automobile dirt road \\
\hline $\begin{array}{l}\text { Kurai } \\
\text { village }\end{array}$ & 427 & Altai-kizhi & $\begin{array}{l}\text { Driving cattle breeding (sheep } \\
\text { breeding, horse breeding, goat } \\
\text { breeding), hunting }\end{array}$ & $\begin{array}{c}\text { Federal highway P256 } \\
\text { (formerly M52) } \\
\text { "Chuysky tract" }\end{array}$ \\
\hline Beltir village & $\begin{array}{l}\text { Permanent population: } \\
77 \text { people } \\
\text { Seasonal: up to } \\
250 \text { people }\end{array}$ & Telengites & $\begin{array}{l}\text { Driving cattle breeding (sheep } \\
\text { breeding, horse breeding, goat } \\
\text { breeding), hunting }\end{array}$ & Automobile dirt road \\
\hline $\begin{array}{l}\text { Balyktul } \\
\text { village }\end{array}$ & 1340 & Telengites & $\begin{array}{l}\text { Driving cattle breeding (sheep } \\
\text { breeding, horse breeding, goat } \\
\text { breeding), hunting }\end{array}$ & $\begin{array}{l}\text { Automobile road with } \\
\text { a hard surface } \\
\text { "Ulagansky tract" }\end{array}$ \\
\hline $\begin{array}{l}\text { Multa } \\
\text { village }\end{array}$ & 704 & $\begin{array}{l}\text { Russian Old } \\
\text { Believers }\end{array}$ & $\begin{array}{l}\text { Agriculture (cultivation of grain and } \\
\text { cereal crops), truck farming, cattle } \\
\text { breeding, horse breeding, maral } \\
\text { breeding, beekeeping, hunting, } \\
\text { fishing, gathering wild plants }\end{array}$ & $\begin{array}{l}\text { Uimonsky tract } \\
\text { hard-surfaced } \\
\text { automobile road }\end{array}$ \\
\hline $\begin{array}{l}\text { Karagay } \\
\text { village }\end{array}$ & 446 & $\begin{array}{l}\text { Russian Old } \\
\text { Believers }\end{array}$ & $\begin{array}{c}\text { Maral breeding, horse breeding, cattle } \\
\text { breeding, beekeeping, horticulture, } \\
\text { hunting, fishing }\end{array}$ & Soil-gravel road \\
\hline
\end{tabular}

The administrative center is the village of Toora-Khem. Distance from the village of Toora-Khem to Kyzyl is $230 \mathrm{~km}$ by land, $285 \mathrm{~km}$ by water, $170 \mathrm{~km}$ by air. Todzhins are considered as subgroup of Tuvans, most of whom live in four settlements of the Todzha region.

These are the villages of Adyr-Kezhig, Iy, Kham-Syra and Systyg-Khem. The population of these four settlements is almost entirely made up of ethnic Todjins [35]. Traditional types of nature use by Todzha people are mountain-forest reindeer husbandry with the auxiliary role of hunting and fishing.

The southernmost reindeer breeding area in the world is located here. Isolation from large settlement centers ensured a high degree of preservation of unique traditional cultural landscapes [36].

In the territory of Todzhinsky kozhuun, 14 territorial-neighboring and tribal communities of indigenous small-numbered peoples of Tuvinians-Todzha are registered. 


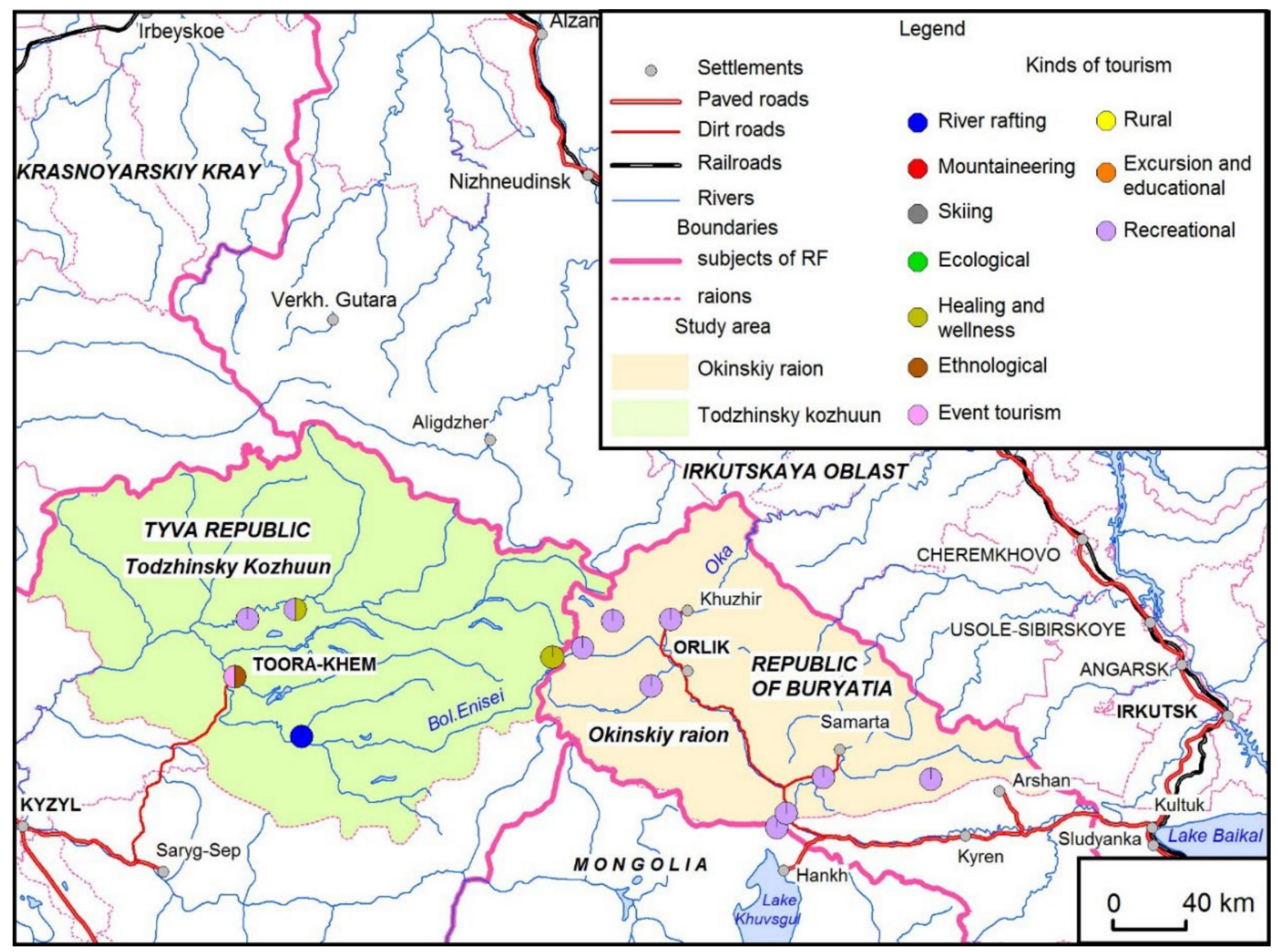

Figure 2. Map of the Okinsky district and Todzhinsky kozhuun.

In the "List of places of traditional residence and traditional economic activities of the indigenous peoples of the Russian Federation" and the "List of types of traditional economic activities of the indigenous peoples of the Russian Federation" were incorporated the rural settlements (sumons), Republic of Tuva: Azassky, Iysky, Systyg-Khemsky, Chazylarsky and Todzhinsky kozhuun. There are still no special territories of traditional nature use officially assigned to communities on the territory of Todzhinsky kozhuun, but this topic is very relevant, and is raised by Tuvans-Todzha at diverse events [37].

The Todzhinsky kozhuun is rich with natural resources. A number of gold deposits are being mined here.

The village of Toora-Khem is a regional center located in Todzha valley, on Biy-Khem river, at the confluence of the Toora-Khem river. In Toora-Khem, with a population of 3160 people, $48.7 \%$ of the total population are Todzhinsky kozhuun [38].

\subsection{Case 2. Okinsky District, Republic of Buryatia}

The Okinsky district of the Republic of Buryatia, with the center in the village of Orlik, is located in the Eastern Sayan Mountains (Figure 2). It borders with Todzhinsky kozhuun, the Republic of Buryatia in the south, and southeast along the watershed of Tunkinskiye Goltsy Ridge. In the north and east, it adjoins the Irkutsk region, and in the west, it borders on the Republic of Tyva. The state border with Mongolia runs in the south [39].

The highly mountainous and remote nature of the location of the territory made it possible to preserve traditional activities of indigenous peoples, main direction of which is nomadic pastoralism with a vertical nomadic system [40]. Currently, the following types of traditional practices and land use are represented in the territory: distant pasture animal husbandry (primarily yak breeding), reindeer husbandry, hunting, fishing, and gathering [41]. 
The Okinsky district is included in the "List of places of traditional residence and traditional economic activities of the indigenous peoples of the Russian Federation" and the "List of types of traditional economic activities of the indigenous peoples of the Russian Federation". The territory of the district belongs to the territories of traditional land use [42].

The village of Orlik is the administrative center of the district. The village is located at an altitude of $1376 \mathrm{~m}$ above sea level, on the right bank of the Oka River, near the mouth of the of the same name, Orlik River.

\section{Transport Systems of Todzhinsky Kozhuun and the Okinsky District}

With an increase in the number of mining enterprises, the transport infrastructure of Todzhinsky kozhuun began to develop at an active pace. In 2020, the construction of a bridge across Yenisei, more precisely through its tributary Biy-Khem (Bolshoi Yenisei), began. Now, to get to the regional center of kozhuun, a ferry is used, which operates $24 \mathrm{~h}$ a day. At the moment, the Ak-Sug field is being actively developed and a new ferry for the freight transport of this mining enterprise has been launched, which, if necessary, takes the transport of local residents.

Toora-Khem is connected with Kyzyl and other kozhuuns by a dirt road. Before entering the village, one must cross Bolshaya Yenisei by ferry. Private carriers provide transport services to the population of the kozhuun.

Inter-district transport links organized communication along the route Kyzyl-TooraKhem-Kyzyl on high cross-country vehicles "UAZ", "URAL". Air communication for Kyzyl-Toora-Khem is carried out by AviaGeo LLC. The nearest railway station by road, in the city of Abakan, is $630 \mathrm{~km}$ [43].

From Toora-Khem on dirt roads, one can get to kozhuun villages, such as Iy and Adyr-Kezhig, but the rest of the settlements can only be reached by river transport or by horse.

Toora-Khem, due to limited transport accessibility and an uncomfortable climate, together with Mongun-Taiginsky kozhuun in the Tuva Republic, was recognized as an area of the Far North, despite its southern position, due to its location in the highlands.

Nomadic practices are still supported by some of its male residents, who spend most of the year in the forest and mountains and only live in the village in winter. Compared to other reindeer-breeding regions of other subjects, the transition to automated transport was difficult: even military transport was not always able to overcome the mountain slopes.

During the Soviet period, helicopters were used to transport hunters [44]. However, local traditions of reindeer husbandry were considered, and in addition, isolation and cultural specificity of the republic also allowed the preservation of the traditional use of natural resources [45].

The Boyarovka-Toora-Khem motor road is one of regional and intermunicipal importance. According to the contractors' reports, the road is in satisfactory, passable condition [46]. The construction of main part of the dirt road to Todju, with exception of the bridge over the Biy-Khem River, on which a ferry crossing is carried out in summer, was completed in 2009 [47].

At the moment, the roadbed is being improved by the mining company Lunsin LLC. The residents, in interviews noted, the difference in transport links: "Before the road was made, the travel time from Kyzyl to Toora-Khem was 10 or $12 \mathrm{~h}$, now it is about $5 h^{\prime \prime}$ (wife, local resident, 30 years old, Toora-Khem).

In 2020, the Golevskaya Mining Company began developing an Ak-Sugskiy porphyry copper deposit in the Todzha region. The company assumed obligations for construction of a $220 \mathrm{kV}$ transmission line and the Turan-Yrban highway [48].

Minibuses (passable UAZs) run from Kyzyl to Toora-Khem every day, and up to five cars a day can go (depends on demand).

To ensure aviation communication between the Todzha region and Kyzyl, a TooraKhem landing site is located in the regional center. As far as airfields are concerned airfields, the Todzha Aviation Department of the State Autonomous Institution of the Republic of 
Tatarstan Avialesokhrana operates in the region, and forest protection is carried out on AN-2 aircraft. For the resident population there are subsidized flights to Kyzyl via MI-8 helicopters [49].

The Orlik settlement is the final point of the republican road Mondy-Orlik, a branch of the federal highway A333 Kultuk-Mondy (the border with Mongolia). Air traffic was carried out on a regular basis during Soviet period.

Today, air traffic is carried out extremely rarely and only in emergency situations, for example, in the case of emergency care for a seriously ill patient [50]. The nearest railway station is located $363 \mathrm{~km}$ away in the town of Slyudyanka, Irkutsk Region. From the regional center, one can get to other settlements of the region along gravel roads.

The motor road Mondy-Orlik 81-OP-R3-81K-035 with a length of $134 \mathrm{~km}$ is a public one of regional importance. Until the 1980s, overland communication between the Okinsky region and the Orlik village with the Tunkinsky region and the rest of Buryatia was performed along Oka trail by pack horses. Minimum travel time from the village of Mondy to the regional center of Orlik was four days [38].

Construction of a gravel road with numerous bridges across the right tributaries of the Oka River started in 1985 and car traffic was opened in 1993. The distance between Orlik and Ulan-Ude, the capital of the Republic of Buryatia, is more than $700 \mathrm{~km}$, of which most of the time it takes to overcome $160 \mathrm{~km}$ of a dirt road from Orlik to Mond, the village of the Tunkinsky district. The road was eroded by floods several times over the past decades, but each time it was promptly rebuilt by gold mining companies.

An official minibus runs from Orlik to Ulan-Ude every day. An unofficial minibus runs from Orlik to Irkutsk once or twice a week.

\subsection{Case 3. Tyndinsky District, Amur Region}

The district is located in the northwestern part of the Amur Region and borders on the west with the Trans-Baikal Territory, in the north and northwest with the Republic of Sakha (Yakutia), in the east with Zeya, in the southeast with Magdagachinsky, and in the south with Skovorodinsky districts of the Amur Region (Figure 3). The area is severely multinational.

Evenks live in three settlements of the region (Ust-Nyukzha, Ust-Urkima, and Pervomaiskoe). These three settlements are included in the "List of places of traditional residence and traditional economic activities of the indigenous peoples of the Russian Federation" and the "List of types of traditional economic activities of the indigenous peoples of the Russian Federation". Territories of traditional nature used in the Amur Region, despite existence of a legislative base, have not been created. The traditional industry of the indigenous Evenk population is hunting, fishing, and reindeer herding. The Tyndinsky district is a mountainous area dominated by middle and low mountains. As a result of frost weathering, heaps of stone debris-curums-appear.

In the northern part of the territory there is the largest mountain ridge, Stanovaya, but the district includes only southern slopes of the ridge, stretching from the Olekma River in the west and to the upper reaches of the Uchur in the east. In southern parts of the region, the mountain system of Yankan-Tukuringra-Soktakhan-Dzhagdy stretches from west to east. This is a medium-altitude mountain range with absolute marks up to $1400-1600 \mathrm{~m}$.

Ust-Urkima is a village located $150 \mathrm{~km}$ northwest of the regional center of Tynda. The village was formed in 1935 and is the administrative center of the Nyukzhinsky village council. The village is located at the mouth of the Urkim River.

Ust-Urkima is a village located $150 \mathrm{~km}$ northwest of Tynda. The village was founded in 1935 and is the administrative center of the Nyukzhinsky village council. The village is located at the mouth of the Urkim River.

Three gold mining enterprises, located $15 \mathrm{~km}$ from the village, are extracting loose and ore gold. 


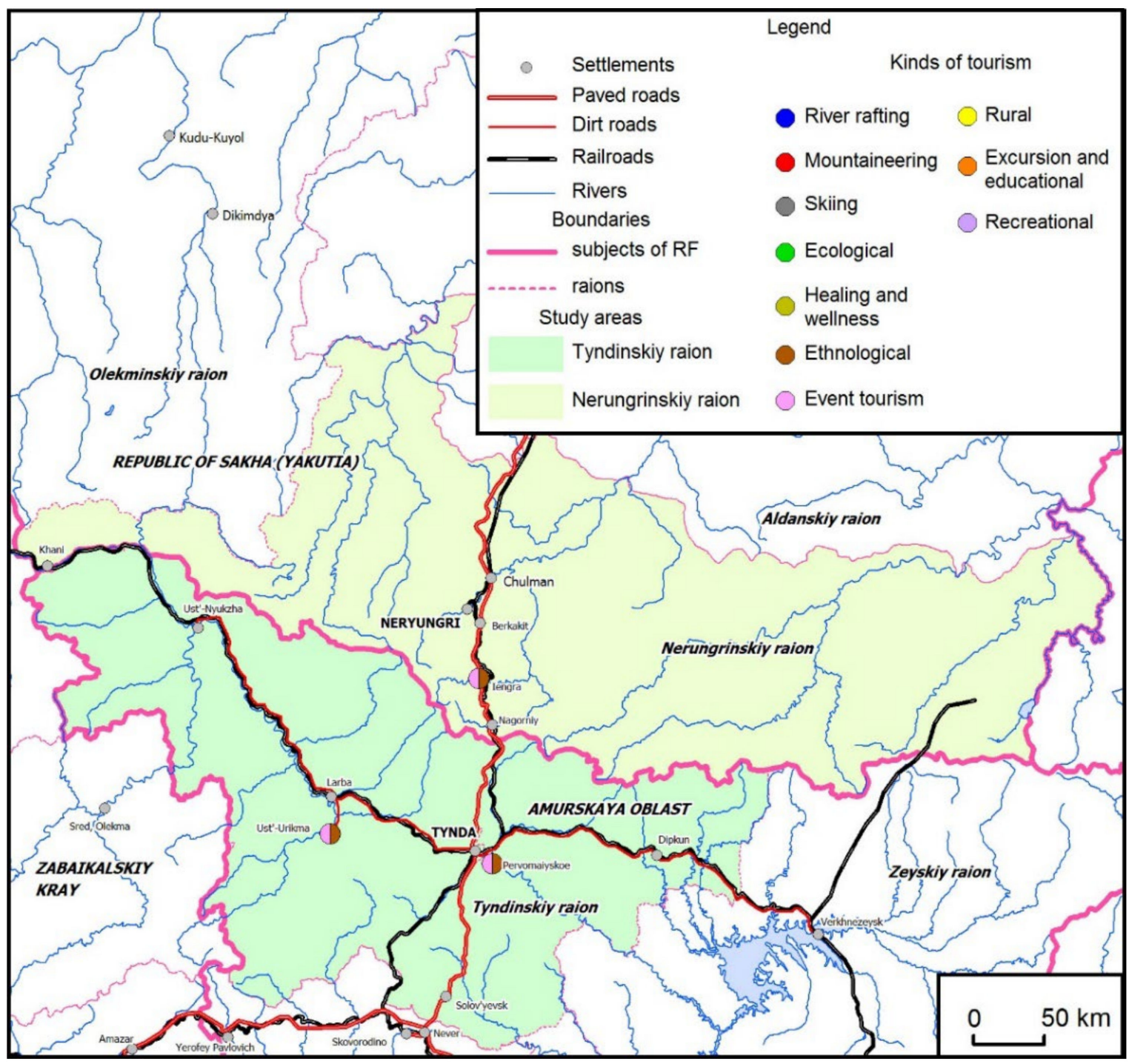

Figure 3. Tyndinsky district of the Amur Region and Neryungrinsky district of the Republic of Sakha (Yakutia).

\subsection{Case 4. Neryungri District, Republic of Sakha (Yakutia)}

The district is located in the south of the Republic of Sakha (Yakutia) in spurs of the Stanovoy Range (Figure 3). Its area is 98.8 thousand square $\mathrm{km}$. The district abuts the Olekminsky district (in the west) and the Aldan district (in the north) both of the Republic of Sakha (Yakutia). It neighbors the Khabarovsk Territory in the southeast, the Amur Region in the south, and the Trans-Baikal Territory in the southwest.

The relief is mountainous, and most of it is occupied by Aldan Highlands, in the south part of the Stanovoy Range. The climate of the region is sharply continental with severe, long winters and short, warm summers.

The territory is one of the main areas filled with mineral resources and industrialized regions of the Republic of Sakha (Yakutia). The economy of the district is based on industries specializing in coal and gold mining, power generation, and transport. A total of 145 large- and medium-sized enterprises operate on the territory. The agro-industrial complex is represented by several agricultural enterprises: Saysary JSC, Zolotinka Municipal Unitary Enterprise, Iengra Municipal Unitary Enterprise, Yuzhno-Yakutskoe Agricultural Production Complex, 5 peasant (farmer) households, and 30 nomadic tribal communities. Iengra is the administrative center and the only settlement of the municipality "Iengri Evenk National Nasleg". The village was founded in 1926 and originally had the name 
Zolotinka, but in 1977 it was renamed to Iengra. Located on the left bank of the river of the same name, $51 \mathrm{~km}$ from the regional center, is the city of Neryungri.

Iengra is the only village in the Neryungri district where indigenous people, the Evenks, originally lived. The village is also included in the "List of places of traditional residence and traditional economic activities of the indigenous peoples of the Russian Federation" and the "List of types of traditional economic activities of the indigenous peoples of the Russian Federation".

It is only in this location where language, culture, and national traditions of reindeer husbandry have been preserved in general. On 1 January 2019, 30 tribal communities of indigenous minorities were registered in the Iengri territory, with 61 people. The main occupation of the village population is reindeer herding. The main activity of the "Iengra" Company is also reindeer breeding, as well as breeding fur animals on farms, hunting and trapping wild animals, and trading in meat and poultry meat, including offal.

\section{Transport System of Tynda and Neryungri Districts}

Development of the Tynda and Neryungri districts is historically interconnected because of their geographical and economic position as a comprehensive territorial-production and transport system. Their geographical position and specificity of economic specialization have determined a high level of development of rail, road, and air transport.

The Amur Region is located on the most important connecting links of the Russian transport corridors with the countries of the Asia-Pacific region along the Trans-Siberian and Baikal-Amur Mainlines, the Amur River, the Amur (Chita-Khabarovsk) and Lena (NeverYakutsk) highways, the Polyarnaya-4 international cross-polar highway, and through the oil pipeline system "Eastern Siberia-Pacific Ocean".

A major railway transport artery of Russia, the Amuro-Yakutsk mainline and the A360 Lena federal highway, pass through the city of Tynda, and because of this, the population living in both the Neryungrinsky and Tyndinsky districts has regular railway communication with Moscow, Blagoveshchensky, Yakutsk, Khabarovsk, Komsomolsk-onAmur, Kislovodsk, and Anapa. Development of the railway leads to increased freight traffic in all directions, and due to reconstruction of the Lena federal highway, an improvement in transport accessibility of the district has been observed.

In the Neryungri district, all settlements have a year-round road connection with the exception of Khani, where there is only a railway connection. In the immediate vicinity of the village of Iengra, there is a railway and the federal highway M56 "Lena". A regular bus on the Neryungri-Iengra route runs two times a day. One can also get to the village by taxi.

Air transport of the Neryungri district is performed by the airport located in Chulman Village. Tynda Airport is a regional site located $13 \mathrm{~km}$ north from Tynda City.

Highways from the Tynda to Urkim quarry of the Priisk Solovyevsky Company and to the mining community of the Druzhba Company pass through territory of the village of Ust-Urkima. Twenty-eight $\mathrm{km}$ from the village of Ust-Urkima, there is a railway station called "Larba". Evenks live on the territory of the village, and they are engaged in fishing, reindeer husbandry, and hunting.

\subsection{Case 5. Republic of Altai}

The Altai Republic is located in the southwestern region of Siberia and covers almost the entire Russian part of Altai's mountainous terrain. The state borders three foreign states-China, Mongolia, and Kazakhstan — passes through the territory (Figure 4).

Also, the Altai Republic abuts on the borders of four other constituent entities of the Russian Federation - the Altai Territory, the Kemerovo Region, the Republic of Khakassia, and the Republic of Tyva. The area of the Altai Republic is $92,600 \mathrm{~km}^{2}$.

The highest ridges and mountain peaks of Siberia are located here, including Mount Belukha $(4506 \mathrm{~m})$. This is a terrain of large modern glaciation and outstanding landscape diversity. 


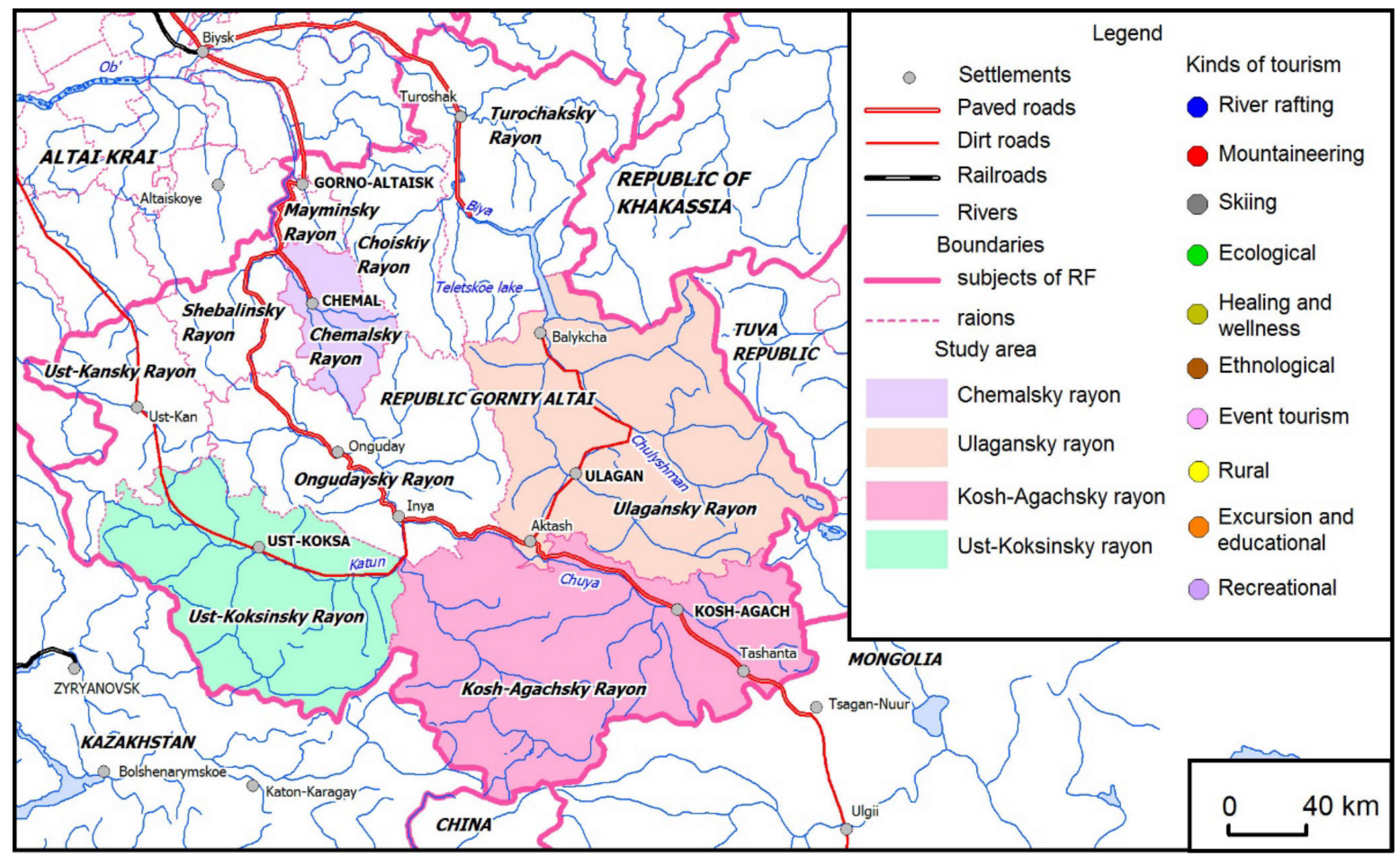

Figure 4. Altai Republic.

In 1998, five clusters (Lake Teletskoye, Altai Biosphere Reserve, Katunsky Biosphere Reserve, Belukha Mountain, Ukok Plateau) were included in the UNESCO World Heritage List under the general name "Golden Mountains of Altai" [51].

The centuries-old processes of cultural genesis of Altai, which at different times were part of various state formations and was the arena of interaction between different civilizations, have preserved a rich cultural heritage, such as numerous petroglyphs, ancient burial mounds, balbals, etc. Many archaeological finds (Pazyryk burial mounds [52], “Denisovsky man" [53,54], “Ukok princess" [55]) are of global importance.

Currently, the region is home to several ethnic groups, including relatively isolated indigenous minority groups. The autochthonous Turkic-speaking peoples of Altai, according to the accepted ethnographic classification, include two groups that unite several ethnic groups: the northern Altaians (Tubalars, Chelkans, Kumandins) and the southern Altaians (Altai-Kizhi and Telengits). Many communities practice their traditional lifestyles with livestock, hunting, and forestry activities.

At present, a key branch of economy of the Altai Republic is agriculture, mainly in the livestock sector. Antler maral breeding is the greatest economic value and export orientation. Antlers (young maral horns) are preserved and used for medical purposes and pharmaceuticals.

Sheep breeding, horse breeding, cattle breeding, and beekeeping also play an important role in the economic complex. Tourism is the second most important sector in the structure of the regional economy. Also in the Altai Republic, diverse companies work in timber harvesting and woodworking, as well as harvesting medicinal plants and other biological resources. The regional mining industry is involved in gold mining.

Traditional culture of the indigenous peoples of the North in Altai is preserved and reproduced mainly in terrains which are remote from the centers of economic activity and those which are underdeveloped. These include the selected model regions of Chemalsky (partially), Ust-Koksinsky, Ulagansky, and Kosh-Agachsky. 


\subsection{Transport System of the Altai Republic}

The mountainous relief of the territory is made up of a system of ridges, river valleys, and intermontane basins that determine the main spatial patterns of development (including transport and tourism) of the territory and population settlement.

Almost all settlements and roads are located in wide sections of the valleys of large rivers: Katun, Biya, Chuya, Koksa, and Charysh; as well as in intermontane basins: Uimonskaya, Abayskaya, Kanskaya, Katandinskaya, Kuraiskaya, and Chuiskaya. Currently, there is no railway transport in the Altai Republic. Air transport has also been underdeveloped so far. The only federal airport, Gorno-Altaysk, is located in the northern part of the republic, not far from the regional center. There is no regular domestic air service. Water transport is represented only by a conditionally regular service between the northern and southern shores of Lake Teletskoye (there is a ferry running twice a week, as well as excursion boats), mainly implied for tourists.

Thus, in fact, the only mode of transport in the Altai Republic is by automobile, which greatly increases the importance of the development of road infrastructure for the socioeconomic development of the region.

The main transport artery of the region is the federal highway R-256, the (previously it had the designation M-52) "Chuisky tract", connecting the Altai Republic with the Altai Territory and, further, the Novosibirsk Region, crossing the republic itself from north to south along the valleys of the Katun and Chuya rivers, and extending further to Mongolia. The route is part of the Asian route AH4 (Novosibirsk-Biysk-Yarantai (Mongolia)-UrumqiIslamabad-Karachi).

It is the Chuysky tract that is the main pivot of the territorial socioeconomic system of this region, on which the largest settlements and areas of economic activity are "strung". The only city and regional center of the republic of Gorno-Altaysk, are the regional centers of Maima, Shebalino, Ongudai, and Kosh-Agach, and the large villages of Manzherok, Souzga, Cherga, Aktash are located on the Chuisky tract.

\section{Results and Discussion}

\subsection{Inter-Development of Transportation Networks and Tourism Industry in the Study Areas}

\subsubsection{Tourism Development in the Todzhinsky Kozhuun and Okinsky Districts}

The area under consideration is bounded by Eastern Sayan from the north, by Academician Obruchev ridge from the south and by Western Sayan from the west. The central part is represented by the vast Todzha Valley, the main drainage rivers of which are Bolshoi Yenisei, Azas, and Khamsara. At the bottom of the valley basin there are quite large and picturesque lakes: Noyon-Khol and Todzha (Azas). The territorial transport infrastructure is extremely underdeveloped. Basically, it includes automobile transport, air transport, and a tiny portion of water and equestrian transport. In connection with mineral exploitation, road network is being actively developed. However, currently, the regional center TooraKhem is connected with Kyzyl, the capital of the Tuva Republic and other kozhuuns, by a dirt road.

A total of 32 arzhaans (mineral springs) are known of in the territory of Todzhinsky kozhuun. The most popular for treatment are Choigan, Kizhi-Khemskaya (Aryskan, Chymchak-Khem, Uran-Sai, and Shandal-oi), Olbuksky, and Maimalysh (Myya-Khash springs). Rivers and lakes of Todzha Valley, rich in valuable fish, attract attention of water tourism enthusiasts and sports fishermen.

To protect the nature of northeastern Tuva in 1985, the state natural reserve "Azas" was formed in Todzhinsky kozhuun. Its area is 333,884 hectares. The reserve includes an estuary part of Azas Lake and further extends along the Azas River to the high Eastern Sayan Mountains bordering Buryatia.

According to the 2020 tourist passport of Todzhinsky kozhuun [56], the most promising types of tourism in Todzhinsky kozhuun, considering trends in tourist demand in the Russian market, are: 
- health-improvement: (therapeutic and healing spring (arzhaans) "Choigan” (Izig-Sug), Olbuk, Nogaan-Khol, and Myima-Khash.

- event tourism: (Festival of reindeer breeders of Todzha kozhuun, National holiday "NAADYM", International Day of the Indigenous Minorities of the North, Siberia and the Far East, Republican competition with Todzha sketches "Tozhuayannary");

- business: business meetings with representatives of the government and the Ministry of the Republic of Tyva;

- cultural and educational tourism: ecological routes "by the path of reindeer people" through picturesque places of kozhuun on the territory of the "Azas" reserve, the place of Kyzyl-Dash for children and adults.

- recreational tourism: Lake Azas, Lake Dorug-Khol, and Lake Albuk.

In general, the picturesque landscapes of the area, including high mountains with a system of lakes, peaks, and volcanoes, attract a fairly large number of tourists.

It should be noted that the development level of tourist infrastructure is extremely low. In total, there are six tourist bases and collective accommodation facilities on the territory of Todzhinsky kozhuun. Tourist attractions and approaches/entrances to them are practically not equipped. The tourist flow in the territory of the district in 2018 was registered as 3693 people, and in 2019, more than 6000 people.

In order to increase internal and inbound tourist flow, the Administration of Todzha kozhuun provides grading and profiling roads in directions of the Azas and Olbuk lakes, and the villages of Adyr-Kezhig and Iy [56].

In geographical literature, the region of compact residences of Sayan indigenous peoples in the territory of Russia (Todzhins, Soyts, Tofalars) and Mongolia (Tsaatans) was called Sayan crossroads [57].

In the area of the Sayan crossroads [38], pertinent structural relationships and dynamics of a complex territorial system are clearly visible, uniting not only tourist and road transport sectors, but also its other components.

The eastern part of Sayan crossroads is under the administration of the Okinsky district of the Republic of Buryatia. The latter, until recently, also had a poorly developed transport infrastructure. Due to the construction of mining and processing enterprises focused mainly on gold mining, the region has become more accessible. Regular car traffic began functioning in the early 1990s in connection with the construction of the MondyOrlik highway. Currently, this road has been reconstructed with carriageway widening. Transport communication within the region is provided on unpaved roads, and encounters such problem as water crossings. During summer floods, part of the settlements on the left bank of the main waterway of the river Oka is cut off from the outside world. In winter, due to the appearance of ice, a significant role is played by ice roads used for preparing firewood, hunting, and delivering food to summer pastures.

For tourism development at the Sayan crossroads, the presence of a large number of mineral springs with unique balneological properties are of special importance. However, development of health resort areas is constrained by the lack of and poor transport infrastructure. There are prospects for rural tourism in the region, since the cattle-breeding industry, specific for Russia, has matured here, including yak breeding, as well as deeply preserved the traditional, semi-nomadic lifestyle of the local population.

The Okinsky district is interesting from the point of view of health tourism [58]. The most interesting aspect of tourist and recreational resources are mineral waters. Their great diversity is set upon the complex geological structure of the region, its high neotectonic activity, and recent volcanic activity. A significant part of mineral water springs are located at high altitudes with absolute marks of 1500-1700 m (Shutkhulai, Shumak) and are confined to river valleys [59].

In the 1990s, a sanatorium with five buildings, a dining room, a swimming pool, and a pipe from hot springs to heat one of the buildings was built near the Khoytogol springs. However, due to the transfer of tax payments to republican and federal budgets and lack of 
competent management, the sanatorium was closed. The remains of its infrastructure are used by tourists and local residents, free of charge

Tuvans-Todjins and Soyots continue to maintain their cultural autonomy (including due to their remoteness), which is also attractive for tourists. Improving transport infrastructure is viewed by local residents through the prism of its attendant advantages and disadvantages.

\subsubsection{Tyndinsky District}

The favorable geographical position and rich environmental potential of the Tyndinsky district, its cultural and historical heritage, and the presence of settlements where Evenks live their traditional way of life make it possible to organize developing various areas of tourist activity on the district territory.

The territory includes several state environment reserves of regional significance: botanical ones (Imangra, Olekminsky, and Ulegir) and zoological ones (Lopchinsky and Urkansky). Archaeological sites and petroglyphs are located on banks of the Olekma River [60].

Today, Tynda is a large transport hub in the northwestern Amur Region, where the Taishet-Ural and the Bamovskaya-Berkakit lines intersect. The city has many monuments, and most of them are dedicated to the construction of the Baikal-Amur Mainline [61].

In the vicinity of Tynda, there are natural mineral springs that can be used for recreational purposes (Shakhtaumsky, Sigiktinsky, Ust-Gektansky, Tyndinsky, etc.) [62]. Promising domains for tourism development in the district are industrial tourism, where one can visit gold mining enterprises, observe the processes of gold mining, and its processing, as well as tourist routes by railway.

In the Tyndinsky district, all the prerequisites for the development of skiing are present, and as a consequence, a sports school has been organized, and various competitions are held there. The ski slope "Ust-Koral" is located within the city of Tynda on one of the hills, and the skiing season usually lasts from October to April. After opening in 2007, only a single track was completed, which was about $450 \mathrm{~m}$ long with a height difference of $92 \mathrm{~m}$. There is modern equipment for artificially snowing the slope, and a working lift.

The unique ethnocultural rituals and customs of the Evenks living in the villages of Ust-Nyukzha, Ust-Urkima, and Pervomaiskoye can become platforms for development of ethnographic tourism. Here, Evenk traditions are maintained by the way of life and in folk crafts, such as manufacturing leather goods, fur, and beadwork. Everyday life, crafts, national cuisine, traditions of reindeer husbandry, shamanism, and herbal treatment are of great interest to tourists. Every March in the villages, Reindeer Herder's Day is organized; reindeer races are held and reindeer breeders are honored. At the event, one can also taste the national cuisine of Evenks, see traditional rituals, dances, games, etc. Every year in June, the national Evenk holiday Bakaldyn takes place; as the beginning of the new year during this time, meetings of Evenk clans are held, goods are exchanged, and competitions in national sports are organized, such as mas-wrestling (pulling a stick), jumping over sledges, throwing Evenk lassos for accuracy, and triple jumps.

To preserve the traditional culture and lifestyle of Evenks under the program "Development and preservation of culture and art of the Amur region", in 2012 near the village Pervomayskoye, a museum-tourist complex "Evenk Village" was opened. Main attractions of the Evenk Village are the "Evenk Cultural Center", a museum, workshops, a hunting lodge, a modern house of Evenk family, a hunter's house and dugout, a traditional bathhouse, storage sheds (a canopy for storing supplies), plague, national buildings, abn and shop where locals sell handmade souvenirs.

The Evenk villages of Ust-Nyukzha and Ust-Urkima, where traditional folk crafts are preserved, are interesting for tourists to visit. Tourists in Ust-Urkim can visit the "Golden Thread" workshop, where high fur boots, amulets, and various souvenirs are made. The workshop belongs to the tribal community of indigenous peoples of North "Nyukzhakan", which is engaged in hunting and reindeer husbandry. From 2021, the 
community has planned to organize a special tour. The tour implies participation in festive events dedicated to the Day of the Reindeer Herder, which includes a trip to the camp and visits to attractions. Accommodation for tourists is offered at the taiga base "Sivagli", which is $55 \mathrm{~km}$ from the village. Ust-Urkim. The tour is planned for five days, two days of which one spends on the road from Blagoveshchensk. The estimated cost is about 30,000 rubles per person. It includes accommodation, meals and transfers, as well as a trip on all-terrain vehicles through the taiga. Tourists are invited to feel the life of Evenks, if they wish, to take part in a nomad (change of parking place). In addition, one can take part in master classes where local craftsmen will teach you how to embroider with beads, and sew fur clothes, shoes, and souvenirs. In winter, tourists can go for a ride on deer or go ice fishing, and in summer one can pick berries, mushrooms, and herbs [63].

Tourism development here is impacted by the presence of transport infrastructure; the federal highway A-360 "Lena" and the Amur-Yakutsk Highway connects the cities of Never and Yakutsk. The city of Tynda is a junction station at the intersection of the "small" and "big" Baikal-Amur Mainline with direct access to the Trans-Siberian Railway. Despite good transport accessibility, significant distance from the regional capital, Blagoveshchensk, is a constraining factor for tourism development in the Tyndinsky district. Tyndinsky natural and recreational resources are less developed in terms of tourism in comparison with other areas of the Yakutia Region, which is explained by later development of the territory and the desire of the local population to go on vacation to southern regions of Russia. However, despite this, development of tourism in the Tyndinsky district has great prospects and potential.

\subsubsection{Neryungri District}

Tourism development in the Neryungri Region is favored by the unique geographical position and ecological situation. On the territory of the region there is a remarkable thermal spring "Nakhot", in which the temperature in winter does not drop below 34 degrees. The recreation center "Nakhot" is open all year round.

Development of ecological tourism in this area is associated with specially protected natural areas of the district. The resource reserves of republican significance, such as "Bolshoye Tokko" and "Ungra", and the resource reserves of local significance, including "Khatym" and "Vostok", are located here. In the Neryungri district, water tourism is very popular and widely expanded. Tourist rafting takes place along the rivers Aldan, Ungra, Timpton and Chulman, located in specially protected areas. The routes include hunting and fishing and usually cover uninhabited and off-road areas.

Water tourism in the territory is seasonal and is mainly carried out during summer months. Natural attractions on the territory are "Bottle Rock" and the natural monuments "Aldan Islands" and Timpton Cascade. These objects are also located in hard-toreach places.

Presence of mountains contributes to the development of sports tourism in the district. The Petrovy Gory ski center, the Gorizont ski center, and the Snegovik ski center are located here. Not only do residents of the republic practice extreme sports, but Neryungri residents themselves come to the district as well as residents from neighboring regions, especially from the Amur Region, facilitated by the presence of roads and railways.

Unfortunately, the hotel infrastructure is represented by only 20 hotels located in the city of Neryungri. There are no tourist infrastructures in other settlements and in the territories where tourists visit objects.

An important component in the future of tourism development belongs to the territorial proximity of the national settlement of indigenous peoples, i.e., the village of Iengra. Evenks living in this village preserve their traditional crafts, language, culture, and national traditions. In the village, there is a museum of Evenk ethnography and the Eyan ethnocultural center, which are attractions for visitors. Other objects of special interest to tourists are located in the places of nomadic Evenks and the territories of nomadic tribal communities, to which there are no roads. 
However, there are still no tourism facilities and tourist infrastructure in the village, with the exception of the tourism event "Day of the Reindeer Herder". This holiday is held in March in the village, which is mainly visited by residents of the Neryungri district, who come to the holiday in the morning and go back in the evening.

Tourism development in the village of Iengra is seriously influenced by the current economic situation and general problems associated with it, namely:

- low availability of credit resources with insufficient start-up capital and a weak level of knowledge for a successful start of entrepreneurial activity in the field of tourism;

- high cost of borrowed funds attracted by small- and medium-sized businesses to perform economic activities;

- low share of enterprises in the manufacturing sector, predominance of the trade sector, and low demand for the service sector;

- $\quad$ shortage of qualified personnel and insufficient levels of professional training;

- low entrepreneurial activity of young people.

The greatest interest among tourists is traditional culture and everyday life of the Evenk reindeer herders. Because objects of tourism in the places of residence of Evenks of Iengra and Ust-Urkima are located in areas remote from the villages, which are characterized by an absence of roads and lack of tourist infrastructure, alternative types of transport can be used, such as tracked vehicles (all-terrain vehicle) for travelling in taiga or hovercrafts for water travel.

\subsubsection{Altai Republic}

In this region, interrelations in the "road transport network-tourism" system are clearly pronounced. In other words, roads are not the only factor that determine the conditions for tourism development, but tourism also affects road development. First of all, repair and reconstruction of roads, as well as new road construction, is carried out in popular tourist areas and areas promising for tourism development.

The main federal motorway M-52 "Chuisky tract", which crosses the entire Altai Republic and reaches the border with Mongolia, is maintained in perfect condition. At the same time, it is sections of the Chuisky tract that are most saturated with tourist infrastructure (the lower part of the Katun River Valley within the Maiminsky district of the Altai Republic), which is experiencing the maximum load because of a growing flow of auto tourists that is constantly expanding and improved pertinent infrastructure.

Due to and for tourism development, in lower part of the Katun River valley, but on its opposite bank (already on the territory of the adjacent Altai Territory), a duplicate road was built, unloading the Chuisky tract and ensuring inclusion of tourist activities on the left bank of the Katun River. For the same purpose, several bridges were built across the Katun. This road has become a key factor in the development of a Special Economic Zone of the tourist and recreational type ("Turquoise Katun").

The automobile bridge across the Katun River near the Askat village also predetermined the formation of a new tourist cluster around this village.

The implementation of another major investment project for development of tourist infrastructure - the creation of the Manzherok ski complex-couldn't be realized without road construction.

Transport development of remote territories of Altai gradually begin notably in connection with growing interest among tourists.

A bridge has been built across the Chuya River near the village of Inya, which, after the construction of a 70-kilometer section of road, will allow Tungur-Inegen-Inya to connect the Chuisky tract with the Uimonsky tract near the village of Inya. Thus, the auto tourist route will be looped, providing a smoother visit to the most popular, highly mountainous regions, namely the Ulagan and Kosh-Agach regions adjacent to the Chuisky tract. In this terrain, the popular mountain glacial valleys of the Sever-Chuisky and South Chuisky ranges are located; the road to the "Altai Grand Canyon" (the valley, the Chulyshman River, and on the southern shore of the "younger brother of Baikal") Lake Teletskoye starts; 
picturesque natural and cultural landscapes of high-mountainous steppe and semi-desert basins with the traditional economy of the indigenous Turkic peoples of Altai are presented, and the Ust-Koksinskiy district is crossed by the Uimonsky tract, where the isolated area of residence of Russian Old Believers is located and routes begin towards the highest peaks of Altai, including Mount Belukha and the most beautiful lakes and waterfalls of the Katunsky ridge.

At present, the Uimonsky tract remains a dead end, breaking off in the village of Tungur, which makes it extremely difficult to simultaneously visit different tourist regions of Altai within the same trip. Those who wish to turn off the Chuisky tract onto the Uimonsky tract, in order to drive along it and then return and continue the journey along the Chuisky tract, make a detour of 300 extra kilometers.

For a long time, but so far unsuccessfully, there has been a discussion of the reconstruction of the mountain road without a hard surface, Aktash-Ust-Ulagan-BalyktuyulKatu-Yaryk Pass-Balykcha, and its transformation into a high-quality asphalt highway. However, the conditions for road construction there are extremely difficult and expensive. Therefore, the flow of auto tourists to the Chulyshman Valley has been relatively insignificant so far.

\subsection{Models of Attitudes among Representatives of Indigenous Small People (Communities) towards Transportation and Tourism Development in the Territories}

Our study examines the areas of residence of the indigenous peoples of the North and Siberia with different stages of tourism development. In the Altai Republic, where tourism has been developed for a long time, the Todzhinsky and Okinsky districts, have trends in development of health-improvement and active tourism, and the Tyndinsky and Neryungri districts have cultural holidays, can become a starting point for tourism development in these remote territories.

We have summarized excerpts from interviews with respondents in three tables. Positive and negative attitudes of the local population towards the development of tourism and tourists are presented in Table 4.

In the studied areas, local residents reasonably associate the growth of illegal activities (poaching) with tourism development. Indeed, taking advantage of the factual impossibility of organizing strict control of supervisory services in such remote and vast areas, poachers shoot a large number of rare species of animals, catch fish unlimitedly, and collect valuable plants (for example, golden root, etc.).

Local residents are most dissatisfied with damage that tourists cause to nature. It is often pointed out that tourists leave trash behind, cut trees for fires, and paint landscape rocks with dye. Sometimes the opinion is expressed that tourists who are on vacation demonstrate an idle lifestyle and "waste money", thereby having a negative impact on local culture and "corrupting the youth". Also, in most cases, people distinguish between mass tourism, associated with infrastructure development and habitat transformation, versus active hiking tourism, which is usually not a cause for concern.

It should also be noted that local residents are starting to see the positive aspects of tourism development in the form of an additional source of income from horse rentals, transport services, sale of souvenirs, and provisions of accommodation services. In some cases (in the Altai Republic), representatives of the indigenous population are engaged in the tourism industry, fully linking the welfare of their families with it. However, so far, there are only isolated cases of using culture as a resource for the provision of tourist services. 
Table 4. Positive and negative attitudes of the local population towards the development of tourism and tourists.

\section{+ Positive Attitudes}

"Some take tourists from Orlik to the pass, they also earn money, that is, they provide the Ural truck-, at the pass there are already men with horses, they immediately offer services 1 horse 2.5

thousand (rubles-author) there and back, there you have to go on horseback across the pass ... " [Woman, local resident, 46 years old, Orlik]

“Foreigners came before the Covid restrictions: Chinese, Turks, from Lithuania. Scientists from Tajikistan, other countries, Vladivostok, and Khabarovsk also came.

Tourists are taken away/brought by tablet operators (UAZ car-auth.) ... Some take tourists to the upper reaches of the Yenisei, there is a waterfall, they just take a look... The number of guests is not decreasing, they are constantly populated.

Business travelers come here to work. When the pandemic was, there were no tourists and business travelers, they rarely came here.... There were a lot of tourists in front of the covid, they came from other regions.... When the bridge is built, people will come here more often [Woman, 74 years old, hostess of the hotel, c. Toora-Khem].

"The Evenk village is like an ethnographic complex where events, festivals are held, masters and craftswomen gather, and competitions in northern all-around events are held. We usually spend the Reindeer Herder's Day at the Central Estate. That year the collective came to perform with us, I just want Evenk ... . ... They (the masters of traditional crafts-author) do everything, sell, maybe the sales are not going as we would like, but their products are good, they communicate with each other. Yes, they conduct master classes ... [Woman, administration representative, 42 years old, Pervomaisky]

"We have a lot of tourists. I do not know if the tourists take out fish, I think not. They ride more for the soul. I have friends who take these tourists. But this is exactly about tourists, and there are poachers" (Woman, 35 years old, local resident, Toora-Khem village)

“Tourists with backpacks are a special kind of people. Usually very respectful, intelligent. And they do not stay with us. They will come-backpacks on their shoulders and in the mountains"

[Man, 37 years old, local resident, p. Multa].

\section{- Negative Attitudes}

"Well, they (the tourists-the author) would just drive along the Chuisky tract. Well, on an excursion with a

knowledgeable person who will not allow nature to ruin ... So in fact everywhere they themselves will crawl in their jeeps. All the pastures were plowed up, all the animals were scared away." [Male, 54 years old, local resident, p. Elekmonar]

"I understand, of course, on the territory of the Russian Federation, please, but I want the Okinsko-Tunki park to be made and to be prohibited from sailing along the rivers with their windmills.

So that tourists come just to see. They act in a barbaric way. Sometimes fish are taken out in whole barrels. And we don't know, maybe they hunt, after all, we cannot check everyone, according to the law it is not allowed. There used to be a border zone, until the 1990s, there was a strict regime here and they did not have the right to travel. Tunkinsky, Okinsky, Zakamensky districts-all border areas, if they restored it, I would be very pleased" [Woman, 65 years old, medical worker, p. Orlik).

"They actually tried to motivate people to do this, but we have the specificity of animal husbandry, it is like this, every month there is scheduled in its own way: who, what, when they do ... His main source of income is animal husbandry, which he has known from time immemorial. He knows: I'll raise this calf and in a year and a half he will give me $150 \mathrm{~kg}$ of meat. So, here you also need to step over this one. There is no time to provide services there or has never provided, and now provide? To clean up, wash someone else's bed, wash the baths are the same, well, this one, purely mental" [Male, 49 years old, administration representative, p. Orlik]

"When tourists leave garbage and behave this way, of course, I have a negative attitude. In Viber they write that they waste a lot. But I don't go there, I know that this is happening there"

(Woman, 60 years old, medical worker, Orlik village).

"What is good about mass tourism? People with big money come and behave like the owners of this land and all life.

What entertainment they have on vacation-drunkenness and lewdness. Young people are already morally dissipated, and with such tourism they will finally become corrupted" [Woman, 54 years old, local resident, p. Upper Uimon]

\footnotetext{
"Of course, here now only on marals (Altai subspecies of red deer, whose young antlers are used in pharmaceuticals—author), but you can make money on tourists. My brother and I, for example, offer a transfer in our UAZ vehicles. Basically we will take you to the Lower Multinskoye Lake. For one rise 5000 rubles. And in the leshoz my salary is 20,000 rubles. So consider that it is more profitable if there are people who want to eat every day in the summer. And sometimes twice a day" [Male, 37 years old, local resident, p. Multa].
}

\footnotetext{
"Many people want to visit the Chulyshman valley and drive to the southern shore of Lake Teletskoye, but they are afraid.

Because the road is very bad, the pass is dangerous. If they make a good road, everyone will be fine!" [Male, 48 years old, owner of a camp site, p. Balyktuyul].
}

"If they build this road, everyone will be trampled here. There will be no stone unturned from our beauty ... And there will

be a road, they will immediately start buying land and building hotels. There will be no room for us here" [Man, 37 years old, local resident, p. Multa].

"If Chinese tourists come, we won't get anything from them. Is that rubbish. They will be served by Chinese firms. It's the same all over the world" [Woman, 58 years old, hostess of the guest house, p. Elekmonar]. 
Holidays, such as "Reindeer Breeder's Day", "Naadym", "El-Oyin" and others, are now considered not only as elements of supporting national culture and traditions, but also as an opportunity for development of event-driven tourism and ethno-tourism. Furthermore, remoteness of the terrains allow the preservation of traditional ways of life, culture, and language, thereby increasing attractiveness of the territory in terms of tourism. The masters of traditional crafts who participate in these holidays emphasize such positive aspects of the events as exchange of experience, acquisition of new knowledge, and the opportunity of selling handmade products. Local residents consider the remoteness of the territory from the point of view of calmness, regularity, and preservation of traditions for the good, but negatively in terms of access to medical and other services. Interview excerpts are in Tables 5 and 6.

Table 5. Attitudes of local residents towards the remoteness of the territory of residence.

\section{+ Positive Attitudes}

"The pluses are, of course: the preservation of nature, everyday life, and customs. It is most important" [Male, administration worker, 40 years old, Toora-Khem].

\section{- Negative Attitudes}

"The disadvantages, one can immediately see, in connection with the remoteness-backwardness. We have no new buildings here, have you noticed? If in Kyzyl, for example, it is possible to build a school or a kindergarten for 100 million, we get 130-140, and the question is: where to get these percentages? Therefore, we receive a refusal ... " [Male, administration worker, 40 years old, Toora-Khem]

\footnotetext{
"The Chuisky tract is the road of life for us! All would have left long ago if he had not been there. I myself moved here from Yazula to be closer to civilization. Here, if necessary, you can quickly get to the hospital in Kosh-Agach or call an ambulance-he will come. They bring everything to the shops. And there is none of this. Only the old people were left alone. So my parents stayed there-they don't want to move. Otherwise, I probably would have left for the City. ... A lot of tourists pass by in the summer. People are constantly passing by our house. Sometimes they ask for directions. They go here to Aktru, to the glaciers. My husband and I are thinking of building a guest house in our yard "[Woman, 36 years old, local resident, p. Kurai].
}

"The fact that our village is remote is even good. Nobody bothers, there is a lot of space. It used to be a big village. When the road to Kuyus was made, we had no young people left here. They began to leave. First, to earn money in Chemal (there are a lot of tourists, you can always earn money), and then they stay there forever. And who, in the City (Gorno-Altaysk-author) will go to study. At first, every week they come home-there is a road. And they don't come back after school either" [Male, 62 years old, local resident, Edigan].
"The imprint is made by mountainous terrain, the landscape itself, medium mountains, over $1000 \mathrm{~m}$, all settlements are located at an altitude of over $1000 \mathrm{~m}$. It turns out that we are completely in the mountains, and accordingly we have our own specifics and nuances that leave an imprint in connection with the weather and climatic conditions and the landscape itself, well, in fact, our difficulties.... .

And in this regard, we have many such moments here that are not found in other regions. First of all, these are infrastructural aspects, the transport component, energy, communications. Well, all this comes to us on the sly. The road appeared only in 92 "[Male, administration worker, 49 years old, Orlik].

"In transport, in healthcare, everyone has the same problem. If there was a regular bus, we would know that it will come on Wednesday and we would book for Wednesday to the doctor, to the tax authorities in general to all authorities. It's hard to get to the hospital. Still by appointment. And so they will write us on September 25, and we do not know whether there will be a car at that time. Transport and healthcare are interconnected. Poor transport accessibility. While you leave. You need to find a taxi. Or negotiate with someone. No regular buses. Nothing" [Male, local, 63 yearsold, Ust-Urkima].

In the course of the study, several, and at times, multidirectional trends in the influence of roads on tourism development in the regions inhabited by the indigenous peoples of the Siberia were identified. The study highlighted different types of attitudes of different groups of the population to road construction in the context of tourism development prospects.

The research findings can be grouped into five main plots.

\subsection{1. "The Road of Life" (The Organizing Role of Main Transport Arteries)}

Throughout its course, the Chuisky tract has had a huge impact on sthe ocioeconomic development of the territory. That is what makes it the main territorial planning axis of the Altai Republic. This route provides basic tourist flow to the region, including penetration 
of tourists into its hinterland. The population of the villages located on the Chuisky tract is fully aware of its organizing role.

Table 6. Attitudes of local population towards transport development of their territory (construction and reconstruction of roads).

"We have a regional road, we have always had it, in which we were lucky that we have a regional road"

[Female, administration worker, 38 yearsold, Ust-Urkema].
"I think it's good that we didn't make the road, anyway there is a deterrent factor in any case. Even now, people are driving in bulk, and even though the road is bad ... they also catch our natural resources, kindle fires. It has become very fashionable to come by motorboats and ride to frighten fish" [woman, 47 years old, employee of a cultural institution, p. Orlik].

"You can't build this road to China. There (on the Ukok plateau-author) our ancestors rest. This is a sacred place. When archaeologists got Ms. Ukok (the mummy of a Pazyryk noble woman, excavated by the archaeological expedition N.V. Polosmak in 1993-author), an earthquake occurred, which almost destroyed my native village (Chuy earthquake of 2003 with a magnitude of 7.3 on the scale Richter, who destroyed the village of Beltir-author) [Male, 42 years old, local resident, p. Beltier].

\footnotetext{
"In the sense from Tynda to us, the road is generally ugly. When they do it then it's okay, but it's basically a bad road. Yes, not long ago there was a prosecutor, that's why they did it. This summer the road was very bad because of the rains. Now the road from Larba to Urkema has been made. It is better than all this one, because they carry schoolchildren." Female, local, 62 years old, Ust-Urkema
}

We have seen ourselves that we have a road, asphalt in the area, and then a dirt road, in 2023 it will be asphalted. We are looking forward to it because we crash cars [Female, administration worker, Pervomaisky].
"If a road to China is built, it will become cramped for us here. All the Chinese will occupy. And the first thing that they will do-they will take all our nature into our pockets. They are the ones in their country who treat nature with care, and they do not feel sorry for someone else's. We will have neither leopards nor ibex. No one" [Male, 34 years old, local resident, p. Kurai].

"Nobody will allow to build roads here (in the valleys of the

Akkol and Taldura rivers). This is our land. We won't let anyone in here. If tourists need it, we will take them ourselves.

We also need to live somehow" [Male, 42 years old, local resident, p. Beltier].

A similar role, but at a lower level, is played by other key transport arteries of the region: the Chemalsky, Ulagansky, and Uimonsky tracts, tand the Gorno-Altaisk-ChoyaTurochak Road.

These and many other statements reflect the attitude towards the basic highway of the Republic as its most important resource, ensuring the wellbeing of many families and the very existence of many settlements, a significant part of which increased their population in the post-Soviet period, "pumping out" populations from small and remote villages.

The attitude of the local population towards tourists passing along the Chuisky tract is quite friendly. They see tourism development mainly as a source of income for themselves. However, many of these people disapprove the desire of tourists to leave the Chuisky tract and delve into the little-visited virgin places of Altai.

In this and similar statements, one sees a desire to combine the income that tourists bring (including the provision of excursion services) and the preservation of solitude, intactness and identity in territories remote from the Chuysky tract, where indigenous people remain fully fledged owners and no strangers bother them.

The examples of the Okinsky district and the Todzhinsky kozhuun also demonstrate the high importance of the highway in the development of the districts. The road routes passing in the harsh natural and climatic conditions are the only ground-connecting threads with the "mainland". Bad weather and dangerous natural phenomena, such as landslides, debris, floods, etc., can periodically block these arteries of movement. In these cases, realizing the role that automobile communication plays in the life of the district, local 
administrations are always on standby, including interacting with industrial companies, for which these roads are also the most important way on which the functioning of production depends.

A similar opinion was expressed by residents of the Tynda and Neryungri districts in relation to the federal highway, "Lena", and the railway. The positive aspects were associated with the fact that these roads are provided for the regions and it is a cheap way to travel, first of all, for themselves and their family members (during holidays, student children to the place of study). The negative aspects of the local residents were associated, as in the Altai Republic, with unofficial visits by "outsiders" to remote areas.

\subsection{2. "Escape Route" (Role of New Roads in the Desolation of Rural Areas)}

New road construction, caused by rapid tourism development and the desire to involve new territories in the tourism industry, is usually perceived as an undoubted benefit for the local population, since it provides new opportunities for life support and mobility, attracts investment, and contributes to the creation of new jobs.

However, even before a steady flow of tourists is formed (if it is formed at all), these roads, connecting secluded and, as a rule, depressed villages with more developed territories, contribute to the outflow of the population from them. However, another scenario is possible, as in the case of the village of Iengra, a place with a compact residence of Evenks. The village is located in close proximity to the main road of South Yakutia and in an area of intensive mining for almost 100 years. Because the village is ethnoculturally isolated in the territory of the Neryungri Region, there are no more settlements where representatives of the indigenous population would live, and local residents have no choice of moving to other places where they could live in their traditional environment. As a result of lacking the choice of a moving to a new place, the local population continues to live on their territory.

The outflow of the population from the Okinsky and Todzhinsky districts also takes place; however, the natural increase, due to the persisting traditional forms of reproduction, allows the maintenance of the relative stability of the population in these regions, despite the possibility of moving to more economically developed settlements.

\subsection{3. "Bear's Corner, but Mine" (Unwillingness to Open Their Territories to Mass Tourism)}

For a very long time, there has been the idea of connecting the Uimonsky tract with the Chuysky tract on the Tungur-Inya section $(70 \mathrm{~km})$. In the late $1970 \mathrm{~s}$, not only were surveys performed along the route of the future road, but its construction was started, and the main blasting works were performed and the road was even somewhat prematurely mapped onto geographical maps under the name P373 "Inya-Tungur", of which this "ghost road" still migrates to more modern designs. In fact, this is now a path cut into the slope, along which extreme travels are sometimes arranged by bicycle and motorcycle tourists.

However, in the mid-2000s, due to rapid tourism development, the circular route covering the Chuisky and Uimonsky tracts, which provide the opportunity to visit all the brightest sights of the Altai highlands within one trip, has become more in demand than ever. They again started talking about the construction of the Tungur-Inya Highway and even built a bridge across the Katun in the Ini district.

Currently, the Ust-Koksinsky district is the most important place for the development of hiking and mountain tourism, as well as mountaineering. The villages of the Russian Old Believers (Multa, Upper Uimon, Katanda, and Tungur) became the starting and ending points of popular mountain routes. The local residents, who have become accustomed to self-isolation over the centuries, including the descendants of Russian Old Believers and Altai (Altai-Kizhi) have long become accustomed to the constant presence of hikers and are even gradually included in their service (mainly, organizing a transfer in the highlands on horses or high-pass vehicles, selling honey, pine nuts, etc.). However, the majority of the surveyed local residents have a categorically negative attitude towards the construction of a direct road to the Chuysky tract, which would increase the flow of tourists to the region. 
A similar attitude towards tourists can be seen in Todzhinsky kozhuun and the Okinsky district, where natural beauty attracts tourists, thereby causing anxiety among local residents.

Such a situation is observed in the Tynda and Neryungri districts. Local residents are calm about acquaintances or travel agencies that take tourists to their places, ask them in advance, warn them, or directly involve them. The negative attitude is expressed precisely towards strangers who, without warning or consent, are taken to their places of residence and traditional activities. This attitude towards tourists is similar to the attitude towards representatives of mining companies. There is a positive attitude towards familiar representatives of mining companies who openly cooperate with local authorities and local residents, and negative attitudes towards those who are reluctant to show interest in local residents. In order to show that the presence of "outsiders" in the territories of communities is undesirable, information signs are placed at the borders with information about the community, travel restrictions, and contact details of the head or representative of the community.

Thus, people express fears of an increase in the number of tourists and a change in their "quality". The emergence of the so-called mass tourists (or, as they are called here, "mattress mats"), which, unlike hikers, require comfortable recreation conditions, will attract large businesses, with which the local population will not be able to compete either in tourist services or in the distribution of land plots. Also, mass tourism, in their opinion, will cause irreparable damage to their habitat and the unique cultural landscapes that have developed over the centuries.

An interesting plot is connected with the project for the construction of a direct road to China through the Ukok plateau and the Kanas Pass.

The idea of a direct transport corridor between the Altai Republic and China began to be actively discussed in the late 1990s. Subsequently, the idea of a road was transformed into the project of the Altai transport corridor, which includes a system of pipelines, a road, and a railroad, which will connect two transcontinental transport routes: the Trans-Siberian and Eurasian railways. The implementation of this project automatically includes Altai in the system of world communications. The prospects for increasing tourist flow from China are also enormous.

However, this project faced tough opposition from the local population, namely Telengit communities. Considering that the part of the border between Russia and China within the Altai non-republic is only $54.5 \mathrm{~km}$ and it runs along the centerline of the TabynBogdo-Ola high-mountain massif, the only place where the road could pass was the Ukok plateau and the Kanas pass. These places are sacred to the Telengits. There are many ancient burial places in Ukok from different eras. At the same time, the Telengits consider this place to be a "Zone of Peace", where the spirits of their ancestors live. M. Yu. Shishin believes that Ukok should be perceived only as the "Altar of Eurasia" [64].

Local ecologists also opposed the construction of the road, arguing that the Ukok Plateau is a UNESCO World Heritage Site and capital construction threatens the preservation of its unique ecosystems.

In the case of the road to China, there is also a fear of a violation of the established way of life of the indigenous peoples of Altai, a deterioration in economic and environmental conditions, as well as an important role of mythological consciousness.

\subsection{4. "Off-Road Is My Bread" (How the Local Population Makes Money Off-Road)}

Paradoxically, many representatives of local communities in Altai, Todzha, and Oka are not at all interested in improving the quality of local roads. Attractive for its landscapes of high aesthetic value but hard-to-reach territories, which tourists seek, give the local population an opportunity to earn money.

Organization of the transfer of tourists on high-pass vehicles (GAZ-66, URAL, and UAZ vehicles) or horses to attractions has become a highly profitable and very competitive 
business. The emergence of passable roads there, along which auto-tourists will be able to independently reach their desired locations, will destroy this business.

5.2.5. "Waiting for a Miracle" (Hopes for Improvements Related to Road Development Prospects)

However, for the sake of fairness, it should be noted that among the respondents there were also people who were very hopeful for the improvement of roads and the formation of a stable tourist flow associated with it. Basically, these are those who are already involved in serving tourists and associate the wellbeing of their families with the development of tourist activities.

For example, in the village of Ust-Urkima, the nomadic tribal community "Nyukzhakan" cooperates with travel agencies located in the city of Blagoveshchensk. Accordingly, potential tourists are informed about the possibilities of ethnographic tourism with participation in festive events timed to coincide with the Day of the Reindeer Herder or to attend numerous master classes on traditional crafts in the village of Ust-Urkima. However, problems with logistics make this tourist route unprofitable, since out of the proposed five days of the tour, two days are spent on the road from Blagoveshchensk to Larba (there and back) by rail with a change in Tynda. From the village of Larba, tourists need to independently travel $29 \mathrm{~km}$ by car to the village of Ust-Urkima along a dirt road, which is washed out during the summertime during prolonged rains. In addition, the cost of air tickets from Blagoveshchensk to Tynda is almost three times more expensive than a trip by rail. The local population of the village hopes that the authorities will pay attention to the state of the road connecting their settlement with the nearest railway station, Larba, and raise the issue of regular bus services with the center of the district of Tynda.

In Altai, the respondents also expressed their hopes for early improvement of the transport infrastructure in the areas of their residence, including the formation of a sustainable tourist flow. Thus, many residents of the village of Balyktoyul and the village of Balykcha hope that a good asphalt road will be built along the Chulyshman River Valley to the southern shore of Lake Teletskoye, which will allow them to join the tourism industry.

Thus, as a whole, the results of the current study are comprised from interview-based data, an indigenous, society-centered scope, and a network-driven vision strategy of interrelations between development of transport systems and tourism in the model territories, taking into account natural, socioeconomic, ethnocultural, and institutional factors.

Experts have emphasized the importance of the tourism industry being socially responsible, not only as a commercial initiative but as a partnership in activities to protect the culture and relationship between indigenous people on their own lands [65]. For the most part, contemporary research interest in the studied topic has moved from isolated political, cultural, social, technological, and ecological issues to a tangled and interdependent set of those issues with specific scope, reflecting positions of the indigenous population and oriented to the benefit of the latter $[66,67]$.

In this study, the results of the questionnaire and interviews were compared with the data of a qualitative analysis. Due to the use of qualitative and quantitative methods, a fairly complete picture of interaction and mutual influence of the development of tourism and transport infrastructure was obtained. As the present study has shown, along with questionnaires, it was also necessary to conduct interviews in order to identify details that are often overlooked when using only quantitative methods. This allowed the authors to confidently determine the local population's perception of improved transport accessibility and the attitude of residents to the future development of tourism.

The interview method made it possible to reveal nuances in the variety of connections that exist in complex social processes and phenomena in this study. Interviewing representatives of different groups of stakeholders concerning the development of transport infrastructure and tourism identified various motives and attitudes, which were categorized into five key sociopsychological models. 
This work also reflects opinions on the directions of tourism and transport infrastructure development, and on alternative scenarios for the development of territories that some representatives of the indigenous population would be ready to offer, considering them more productive.

The research we performed focused on local communities with particular emphasis on the interests of indigenous people, not the interests of governments, industrial companies, and people living outside the region. Needs, hopes, and expectations, pros and cons, as well as contradictions and duality in attitudes were taken into consideration. Such a spectrum of attitudes incentivizes building a detailed and transparent description of plans in territory development.

Beyond theoretical digging in indigenous tourism, there is of severe concern in real data depicting attitudes of locals.

New details might be implemented with a conception that indigenous tourism, like nature-based tourism, is in line with needs for post-pandemic recovery.

\section{Conclusions}

As this study of the role of tourism industry in development of remote and inaccessible territories of Siberia confirms, this problem is multifaceted and diverse. It is hard to imagine that tourism, as one of the possible directions for ensuring sustainable development of regions, omits the infrastructure component of the industry. Revealing details of interactions and mutual influences of tourism and the state of accessibility in this work was determined by complex of methods of sociology and statistics on the territories of five constituent entities of Russia, which are comparable and equivalent in many parameters.

It is important that, penetrating into the problem, firstly, the related issues include relations between tourists themselves and workers in the tourism sector who support its functioning in the territories under consideration, including local residents involved in serving tourists. Of course, the interests of the parties here, as a rule, coincide and are focused on increasing the number of tourists and the volume of services provided using an efficient transport network, which includes both modern roads and the convenience of delivering visitors (routes and information). However, fans of indigenous ecotourism and extreme tourism can fall outside of this interest.

The second circle of actors related to the problem is the local population as a whole, and as a rule, representing an indigenous ethnos, which has its own cultural traditions and is engaged in traditional land use, which is an attractive factor for potential tourists. In this circle, while partially recognizing the need and advantages of having a well-functioning transport infrastructure, a significant part of the population expresses a negative attitude towards easy accessibility of the territory for outsiders who violate the rules and regime for the use of natural resources, and who compete with the local population both economically and culturally.

It is quite common that all actors have a desire to combine benefits, both from the presence of tourism industry, and from the convenience of mobility, within the territories as well as traveling outside, while maintaining cultural intactness and identity.

At the same time, modern researchers have not fully revealed the impact of the development of highways on young generation outflow of local residents of the considered territories towards urbanized settlements.

It can also be noted that the problem of interrelations between the tourist industry and industrial companies in the context of road construction has not been sufficiently studied in the territories under consideration. It is important that remote areas often have a unique resource base that is attractive for development, both from national and international investors. Representatives of the mining industry form the third circle of actors related to and interested in the transport infrastructure of the studied territories.

Of course, coordination of interests of multiple parties, with the priority provision of sustainable territorial development, is possible when developing legal and organiza- 
tional instruments with the necessary supporting practices based on deep and thorough systemic research.

The study resulted in the identified fundamental (and not always obvious) patterns of the processes of mutual development of tourism, transport, and indigenous communities in underdeveloped and remote territories, as well as models of the attitude of local communities to the tourist and transport development of their territories.

Some limitations of the work are connected to insufficient usage of rich instruments of network science and the theoretical analysis and numerical modelling.

Nevertheless, the data received in the study will enforce a network platform for further comprehensive research of remote territories just to improve theoretical background of the issue. It also imbeds practically notable value in preparing decision support materials for local and regional administrations, considering attitudes and interests of indigenous populations.

The results promote the clarification of complexities of a terrain system that comprises diverse socioeconomic, technological, and ecological actors and concomitant processes with tangled interconnections and interdependencies. Such clarification might be applicable for sustainable development of remote territories for mutual benefit of locals and industrial and tourism businesses.

Author Contributions: Conceptualisation M.K., V.F., D.D. and A.T.; Writing-original draft preparation, A.S. and A.T.; Writing-review and editing, N.K. and A.F.; Visualisation, V.B. and V.F.; Supervision, A.I. and E.B.; Project administration, D.K.; Funding acquisition, A.S. and A.T. All authors have read and agreed to the published version of the manuscript.

Funding: The reported study was funded by RFBR and MECSS, project number 20-57-44002 “Interdisciplinary network platform for modeling socio-economic and environmental processes in the cross-border territories of the Russian Federation and Mongolia with limited transport accessibility" in terms of collecting field data in the Todzha kozhun (Tyva) and the Okinsky district (Buryatia) and with the support of the Russian Science Foundation No. 21-17-00250" Interregional and intraregional communications of the indigenous peoples of the North in the face of global challenges: history and modernity" in terms of collecting information on the Tyndinsky district (Amur Region) and Neryungrinsky district of the Republic Sakha.

Institutional Review Board Statement: Approval for the study was not required in accordance with Russian national legislation.

Informed Consent Statement: Informed consent was obtained from all subjects involved in the study.

Data Availability Statement: Not applicable.

Conflicts of Interest: The authors declare no conflict of interest. The funders had no role in the design of the study; in the collection, analyses, or interpretation of data; in the writing of the manuscript, or in the decision to publish the results.

\section{References}

1. 17 Goals to Transform Our World. Available online: https://www.un.org/sustainabledevelopment/ru/about/developmentagenda/ (accessed on 15 October 2021).

2. Report of the World Commission on Environment and Development: Our Common Future URL. Available online: https: // sustainabledevelopment.un.org/content/documents/5987our-common-future.pdf (accessed on 15 October 2021).

3. Pirogova, O.V.; Pirogova, A.Y. The role of sustainable tourism in the world. Int. J. Fundam. Appl. Res. 2017, 7, 305-309. [CrossRef]

4. International Council for Local Environmental Initiatives. International Development Research Center and the United Nations Environment Program: Local Agenda: Planning Guide, XXI. Toronto. 1996, p. 178. Available online: https: / / sustainabledevelopment.un.org/content/documents/Agenda21.pdf (accessed on 5 November 2021).

5. Rietveld, P.; Nijkamp, P. Transport and regional development. 1992, p. 22. Available online: https://degree.ubvu.vu.nl/repec/ vua/wpaper/pdf/19920050.pdf (accessed on 15 October 2021).

6. Baird, B.A. Public Infrastructure and Economic Productivity: A Transportation-Focused Review. Transp. Res. Rec. 2005, 1932, 54-60. [CrossRef]

7. Bezrukov, L.A. The Continental-Oceanic Dichotomy in International and Regional Development. Novosibirsk. 2008, p. 369. Available online: https:// earthpapers.net/kontinentalno-okeanicheskaya-dihotomiya-v-mezhdunarodnom-i-regionalnomrazvitii (accessed on 15 October 2021). 
8. Semina, I.A. Regional transport systems: Typology and vectors of development. In Multi-Vector Approach in the Development of Russian Regions: Resources, Strategies and New Trends; Streletsky, V.N., Ed.; IP Matushkina I.I.: Moscow, Russia, 2017; pp. 123-138. [CrossRef]

9. Wang, Y.; Wang, M.; Li, K.; Zhao, J. Analysis of the Relationships between Tourism Efficiency and Transport Accessibility-A Case Study in Hubei Province, China. Sustainability 2021, 13, 8649. [CrossRef]

10. Harvey, P.; Knox, H. The enchantments of infrastructure. Mobilities 2012, 7, 521-536. [CrossRef]

11. Stroeva, G.N.; Slobodchikova, D.V. Ensuring transport accessibility of the population as an important direction of the socioeconomic development of the region. Sci. Notes PNU 2016, 7, 673-679. Available online: https: / / ejournal.pnu.edu.ru/media/ ejournal/articles-2016/TGU_7_280.pdf (accessed on 5 November 2021).

12. Transport strategy of the Russian Federation for the period up to 2030. Available online: http:/ / www.consultant.ru/document/ cons_doc_LAW_82617/12dbe84ab7402c41a061dee3399c090bf6932cc3/ (accessed on 5 November 2021).

13. Harvey, P. The topological quality of infrastructural relation: An ethnographic approach. Theory Cult. Soc. 2012, $29,76-92$. [CrossRef]

14. Dalakoglou, D. The road from capitalism to capitalism: Infrastructures of (post) socialism in Albania. Mobilities 2012, 7, 571-586. [CrossRef]

15. Kuklina, V.V. Transport (in) accessibility: Experience and practices of mobility of residents of settlements in the national republics of Siberia. The Collection of Scientific Papers Based on the Results of the All-Russian Scientific and Practical Seminar: Republics in the East of Russia: Trajectories of Economic, Demographic and Territorial Development. 2018. Available online: https://www.researchgate.net/publication/329711076_TRANSPORTATION_INACCESSIBILITY_EXPERIENCE_ AND_PRACTICES_OF_MOBILITIES_IN_THE_SETTLEMENTS_OF_THE_NATIONAL_REPUBLICS_OF_SIBERIA (accessed on 5 November 2021).

16. Argounova-Low, T. Roads and Roadlessness: Driving trucks in Siberia. J. Ethnol. Folk. 2012, 6, 71-88. Available online: https: / / aura.abdn.ac.uk/bitstream/handle/2164/12273/RoadsandRoadlessness.pdf?sequence=1\&isAllowed=y (accessed on 15 October 2021).

17. Kuklina, V.V.; Osipova, M.E. The role of winter roads in ensuring transport accessibility of the Arctic and subarctic regions of the Republic of Sakha (Yakutia). Soc. Environ. Dev. 2018, 2, 107-112. [CrossRef]

18. Pilyasov, A.N.; Zamyatina, N.; Goncharov, R.V. There is no creativity without mobility: Anthropology of transport in Siberia and the Far East. Spat. Econ. 2019, 15, 149-183. [CrossRef]

19. Marshalova, A.S.; Novoselov, A.S. Competitiveness and development strategy of municipalities. Reg. Econ. Sociol. 2010, 3, 219-236. Available online: https://www.researchgate.net/publication/46525363_Competitiveness_and_development_strategies_ for_municipal_units/link/5e4cf94f458515072da8b53a/download (accessed on 5 November 2021).

20. Schweitzer, P.; Povoroznyuk, O.; Schiesser, S. Beyond wilderness: Towards an anthropology of infrastructure and the built environment in the Russian North. Polar J. 2017, 7, 58-85. [CrossRef] [PubMed]

21. Pozanenko, A.A. Spatial isolation and sustainability of local communities: Towards the development of existing approaches. Bull. Tomsk. State Univ. Philosophy Sociol. Political Sci. 2017, 40, 244-255. [CrossRef]

22. Konstantinov, Y. Roadlessness and the Person: Mode of Travel in the Reindeer Herding Part of the Kola Peninsula. Acta Boreal. 2009, 1, 27-49. [CrossRef]

23. Dirin, D.A.; Madry, C. Transformation processes in traditional nature management systems in the Altai mountain region. In Proceedings of the 17th International Multidisciplinary Scientific GeoConference, Vienna, Austria, 27-29 November 2017; Volume 17, pp. 1015-1024. Available online: https://www.researchgate.net/publication/322930747_TRANSFORMATION_ PROCESSES_IN_TRADITIONAL_NATURE_MANAGEMENT_SYSTEMS_IN_THE_ALTAI_MOUNTAIN_REGION (accessed on 15 October 2021).

24. Dirin, D.; Madry, C. Formation and development factors of Altai ethno-cultural landscapes. In Proceedings of the IOP Conference Series: Earth and Environmental Science, Banda Aceh, Indonesia, 26-27 September 2018; Volume 190. [CrossRef]

25. Groshev, I.L.; Grosheva, I.A.; Grosheva, L.I. Regional Imbalances in the Socio-Economic Development of Russia. Indigenous Peoples: History, Traditions and Modernity; Novosibirsk State Pedagogical University: Novosibirsk, Russia, 2019; pp. 191-200.

26. Ryashchenko, S.V. Regional disparities in the qualitative characteristics of the population of Asian Russia. Geogr. Nat. Resour. 2011, 1, 20-26. [CrossRef]

27. Popova, L.G. Tourism as a resource for territory development. Successes Mod. Nat. Sci. 2007, 12, 90-92. Available online: https: / / natural-sciences.ru/ru/article/view?id=11994 (accessed on 5 November 2021).

28. Bilichenko, I.N.; Kobylkin, D.V.; Kuklina, V.V.; Bogdanov, V.N. Development of the Informal Road Network and its Impact on the Transformation of Taiga Geosystems. Geogr. Nat. Resour. 2021, 42, 148-155. [CrossRef]

29. Bramwell, B.; Lane, B. Sustainable tourism: A developing global approach. J. Sustain. Tour. 1993, 1, 1-5. Available online: https:/ / www.tandfonline.com/doi/abs/10.1080/09669589309450696] (accessed on 5 November 2021).

30. Rasoolimanesh, S.M.; Sundari, R.; Michael Hall, K.; Esfandiar, K.; Seyfi, S. A systematic scoping review of sustainable tourism indicators in relation to the sustainable development goals. J. Sustain. Tour. 2020, pp. 1-21. Available online: https://www. tandfonline.com/doi/full/10.1080/09669582.2020.1775621 (accessed on 5 November 2021).

31. Sustainable Development of Tourism. Sustainable Development of Tourism—World Tourism Organization—Definition. Available online: http:/ / sdt.unwto.org/content/about-us-5 (accessed on 10 November 2021). 
32. Budeanu, A. Impacts and responsibilities for sustainable tourism: A tour operator's perspective. J. Clean. Prod. $2005,13,89-97$. [CrossRef]

33. Ponedelko, G.N. Sustainable Tourism as a Factor in the Regional Development of EU Countries. Regional Economy and Management: Electronic Scientific Journal. Available online: https:/ / eee-region.ru/article/6401/ (accessed on 10 November 2021).

34. Kirchherr, J.; Charles, K. Enhancing the sample diversity of snowball samples: Recommendations from a research project on antidam movements in Southeast Asia. PLoS ONE 2018, 13, e0201710. [CrossRef]

35. Davaa, E.K. Modern sociocultural situation of Tuvinas-Tojins. In Proceedings of the IV International Scientific and Practical Conference Social and Economic Aspects of Education in Modern Society, Warsaw, Poland, 18-19 July 2018; Available online: https:/ /www.researchgate.net/publication/335687834_Proceedings_of_the_IV_International_Scientific_and_Practical_ Conference_Social_and_Economic_Aspects_of_Education_in_Modern_Society/link/5d754297a6fdcc9961ba4b21/download (accessed on 5 November 2021).

36. Dirin, D.A.; Fryer, P. The Sayan borderlands: Tuva's ethnocultural landscapes in changing natural and sociocultural environments. Geogr. Environ. Sustain. 2020, 13, 29-36. [CrossRef]

37. The Popular Front in Tuva Asks the Authorities to Come Up with an Initiative to Change the Legislation on Territories of Traditional Land Use. Available online: https: / onf.ru/2021/10/04/narodnyy-front-v-tuve-prosit-vlasti-vyyti-s-iniciativoy-obizmenenii-zakonodatelstva-o/ (accessed on 10 November 2021).

38. Kuklina, V.; Dashpilov, T. Constructing a map of transport communication "Sayan crossroads". Tartaria Magna. 2013, 2, 12-40.

39. Imetkhenov, A.B. Atlas of the Republic of Buryatia; Federal Service of Geodesy and Cartography of Russia: Moscow, Russia, 2000; p. 48 .

40. Rassadin, I.V. Comparative analysis of animal husbandry of Soyots and Buryats. Humanit. Vector 2017, 12, 190-195. Available online: http:/ / zabvektor.com/wp-content/uploads/080219030207-rassadin.pdf (accessed on 10 November 2021).

41. Kurdyukov, V.N. Traditional Soyot Economy and Its Dynamics. Bull. Irkutsk. State Univ. 2012, 1, 176-185. Available online: https:/ /izvestiageo.isu.ru/en/article/file?id=5 (accessed on 10 November 2021).

42. Gulgenova, S.Z. The history of the development of traditional nature management in the Oka Mountains (Eastern Sayan). Bull. Buryat State Univ. 2009, 4, 24-26. Available online: https:/ / cyberleninka.ru/article/n/istoriya-razvitiya-traditsionnogoprirodopolzovaniya-v-gornoy-oke-vostochnyy-sayan (accessed on 10 November 2021).

43. Dabiev, D.F.; Dabiev, U.M. Socio-Economic characteristic of the Toja district of Tuva. Int. J. Appl. Fundam. Res. 2015, 9, 520-522. Available online: https:/ /s.applied-research.ru/pdf/2015/9-3/7364.pdf (accessed on 10 November 2021).

44. Rassadin, I.V.; Mitkinov, M.K. The study of the material and spiritual culture of the Tofalars: History, modernity, prospects. Bull. Tyumen State Univ. Humanit. Res. 2019, 1, 203-217. Available online: https://vestnik.utmn.ru/upload/iblock/c67/203_217.pdf (accessed on 10 November 2021).

45. Donahoe, B. Who Owns the Taiga? Inclusive vs. Exclusive Senses of Property among the Toju and Tofa of Southern Siberia. Sibirica 2006, 5, 87-116. [CrossRef]

46. Todzhinsky Kozhuun. Official Portal of the Republic of Tyva. Available online: https://rtyva.ru/region/msu/777/ (accessed on 10 November 2021).

47. A Mining and Processing Plant for the Production of Copper, Lead and Zinc Concentrates Is Preparing to Launch in the Tuva Republic. Available online: https://rtyva.ru/press_center/news/building/14651/ (accessed on 10 November 2021).

48. Chinese "Longxing" Launched a Polymetallic Mining and Processing Plant in Tuva. Available online: https://ria.ru (accessed on 30 March 2018).

49. Airlines “Tuva Avia”: Official Website. Available online: http:/ / avia-tuva.ru (accessed on 10 November 2021).

50. Sambyalova, Z.N. The History of the Origin of the Orlik Village. Available online: http://okagazeta.ru/articles/media/2014/7 /21/istoriya-zarozhdeniya-sela-orlik/ (accessed on 15 October 2021).

51. Golden Mountains of Altai (Russian Federation). Available online: https://whc.unesco.org/ru/list/768 (accessed on 30 October 2021).

52. Rudenko, S.I. Frozen Tombs of Siberia: The Pazyryk Burials of Iron Age Horsemen; Thompson, M.W., Ed.; University of California Press: Berkeley, CA, USA, 1970; Available online: https://ehrafarchaeology.yale.edu/ehrafa/citation.do?method=citation\& forward=browseAuthorsFullContext\&id=rl60-002 (accessed on 30 October 2021).

53. Slon, V. The genome of the offspring of a Neanderthal mother and a Denisovan father. Nature 2018, 561, 113-116. [CrossRef]

54. Petr, M. The evolutionary history of Neanderthal and Denisovan Y chromosomes. Science 2020, 369, 1653-1656. [CrossRef]

55. Polosmak, N.V. The burial of a noble Pazyryk woman. Bull. Anc. Hist. 1996, 4, 265. [CrossRef]

56. Tourist passport of the Municipality “Todzhinsky kozhuun of the Tyva Republic". 2020. Available online: http://todzhinsky.ru/ page.php?copylenco=omsu\&id_omsu=17/ (accessed on 10 November 2021).

57. Kalikhman, A.D.; Kalikhman, T.P. Design of the Transboundary Ethno-Natural Protected Area "Sayan Crossroads"; Publishing House of Irkutsk State Technical Universit: Irkutsk, Russia, 2009; p. 106.

58. Rossikhin, A.I. The current state and prospects of tourism development in the East Sayan tourist and recreational mountain territory. In Proceedings of the I International Scientific and Practical Conference, Gorno-Altaisk, Russia, $26-27$ April 2018.

59. Shpeizer, G.M.; Makarov, A.A.; Rodionova, V.A.; Mineeva, L.A. Shumak's mineral waters. Izvestiya Irkutskogo Gosudarstvennogo Universiteta 2012, 5, 293-309. Available online: https:/ / cyberleninka.ru/article/n/shumakskie-mineralnye-vody (accessed on 10 November 2021). 
60. Official Website of the Tyndinsky District. Available online: http:/ / atr.tynda.ru/ (accessed on 31 October 2021).

61. Bus Excursions in Tynda. Available online: https://nashatynda.ru/news/category/dosug/avtobusnye-ekskursii-po-tynde (accessed on 25 October 2021).

62. Holy Spring. Available online: http://svyato.info/amurskaja-oblast/tyndinskijj-rajjon-amurskaja-oblast/ (accessed on 25 October 2021).

63. Day of a Reindeer Breeder and a Hunter in Ust-Urkima. Available online: https:/ /visitamur.ru/tour/den-olenevoda-i-okhotnikav-ust-urkime/\#scroll (accessed on 25 October 2021).

64. Rudoi, A.N.; Lysenkova, Z.V.; Rudsky, V.V.; Shishin, M.Y.; Lysenkova, Z.V.; Rudsky, V.V. Ukok (Past, Present, Future); Publishing house of the Altai State University: Barnaul, Russia, 2000; p. 174.

65. Conceição, S. Indigenous Tourism Critical to Sustainable Future of Travel. Adventure Travel Trade Association. Available online: https://www.adventuretravelnews.com/indigenous-tourism-critical-to-sustainable-future-of-travel (accessed on 25 October 2021).

66. Kuklina, M.; Trufanov, A.; Krasnoshtanova, N.; Urazova, N.; Kobylkin, D.; Bogatyreva, M. Prospects for the Development of Sustainable Tourism in the OkinskyDistrict of the Republic of Buryatia. Sustainability 2021, 13, 8042. [CrossRef]

67. Butler, R. Research on Tourism, Indigenous Peoples and Economic Development: A Missing Component. Land 2021, 10, 1329. [CrossRef] 